\title{
The grain quality of wheat wild relatives in the evolutionary context
}

\author{
Frederike Zeibig ${ }^{1} \cdot$ Benjamin Kilian $^{2}\left(\mathbb{D} \cdot\right.$ Michael Frei $^{1}$ (1)
}

Received: 27 July 2021 / Accepted: 6 December 2021 / Published online: 17 December 2021

(c) The Author(s) 2021

\begin{abstract}
Key message We evaluated the potential of wheat wild relatives for the improvement in grain quality characteristics including micronutrients $(\mathrm{Fe}, \mathrm{Zn})$ and gluten and identified diploid wheats and the timopheevii lineage as the most promising resources.

Abstract Domestication enabled the advancement of civilization through modification of plants according to human requirements. Continuous selection and cultivation of domesticated plants induced genetic bottlenecks. However, ancient diversity has been conserved in crop wild relatives. Wheat (Triticum aestivum L.; Triticum durum Desf.) is one of the most important staple foods and was among the first domesticated crop species. Its evolutionary diversity includes diploid, tetraploid and hexaploid species from the Triticum and Aegilops taxa and different genomes, generating an AA, BBAA/GGAA and BBAADD/GGAAA ${ }^{\mathrm{m}} \mathrm{A}^{\mathrm{m}}$ genepool, respectively. Breeding and improvement in wheat altered its grain quality. In this review, we identified evolutionary patterns and the potential of wheat wild relatives for quality improvement regarding the micronutrients Iron $(\mathrm{Fe})$ and Zinc $(\mathrm{Zn})$, the gluten storage proteins $\alpha$-gliadins and high molecular weight glutenin subunits (HMWGS), and the secondary metabolite phenolics. Generally, the timopheevii lineage has been neglected to date regarding grain quality studies. Thus, the timopheevii lineage should be subject to grain quality research to explore the full diversity of the wheat gene pool.
\end{abstract}

\section{Introduction}

Wheat is one of the world's most important crops. It provides $19 \%$ of human calorie intake and $21 \%$ of protein intake (Shiferaw et al. 2013). Hexaploid bread wheat (Triticum aestivum $\mathrm{L}$., $2 n=6 x=42$, $\mathrm{BBA}^{\mathrm{u}} \mathrm{A}^{\mathrm{u}} \mathrm{DD}$ ) accounts for about $90 \%$ of wheat production, and tetraploid pasta wheat (Triticum durum Desf., $2 n=4 x=28, \mathrm{BBA}^{\mathrm{u}} \mathrm{A}^{\mathrm{u}}$ ) is the 10th most important staple crop (International Grains Council [IGC] (2020). World Grain Statistics 2016). The two economically most important wheat species have different levels of ploidy. This is due to the evolutionary history, in which the process of domestication plays a predominant role (Dubcovsky and Dvorak 2007). Domesticated plants fulfilled the requirements of human cultivation and dietary preference. The main characteristic of domesticated cereals is the loss

Michael Frei

michael.frei@agrar.uni-giessen.de

1 Department of Agronomy and Crop Physiology, Institute of Agronomy and Plant Breeding I, Justus-Liebig-University, 35392 Giessen, Germany

2 Global Crop Diversity Trust, 53113 Bonn, Germany of the ability to survive independently in the wild (Meyer and Purugganan 2013; Purugganan and Fuller 2009; Zohary et al. 2012). The center of wheat diversity and initial domestication lies in the Fertile Crescent. The evolutionary history of wheat is characterized by the allo-polyploidization of the originally diploid Triticum and Aegilops species, which led to the emergence of tetra- and hexaploid wheat species. Human cultivation of the tetraploid wild emmer Triticum dicoccoides (Körn. ex. Aschers. \& Graebner) Schweinf. $\left(2 n=4 x=28, \mathrm{BBA}^{\mathrm{u}} \mathrm{A}^{\mathrm{u}}\right)$ resulted in the emergence of the domesticated Triticum dicoccon Schübl. $(2 n=4 x=28$, BBA $^{\mathrm{u}} \mathrm{A}^{\mathrm{u}}$ ) and later T. durum. The domesticated tetraploid species as well as T. aestivum, of which no direct hexaploid wild relative has yet been identified, expanded their cultivation area by human migration and trade (Kilian et al. 2010; Zohary et al. 2012). Migration from their center of diversity and continuous breeding efforts reduced the genetic diversity of T. aestivum and T. durum (Tanksley and McCouch 1997; Ross-Ibarra et al. 2007). Currently, climatic conditions are changing, posing a threat to the productivity of the cultivated wheats (Zhao et al. 2017; Iizumi et al. 2021; Trnka et al. 2014). The wild and domesticated relatives of wheat are a valuable source of beneficial genetic diversity 
that can be used for crop improvement (Dempewolf et al. 2014; Henry and Nevo 2014; Brozynska et al. 2016; Kilian et al. 2021; Sharma et al. 2021). Wild relatives of wheat are well adapted to their natural habitats, which can be harsh, so they carry useful traits for abiotic stress tolerance (Henry and Nevo 2014; Singh et al. 2012). Their genetic diversity has also been exploited for their resistance to various pests, e.g., hessian fly (Nsarellah et al. 2003) and diseases, such as powdery mildew ( $\mathrm{Li}$ et al. 2020a) and leaf rust (Fatima et al. 2020; Narang et al. 2020). These beneficial traits can be incorporated into modern wheat cultivars via (pre-)breeding programs (Kilian et al. 2011, 2021; Sharma et al. 2021) and thus illustrate the value of this genepool for securing the future cultivation of wheat. In order to harness and conserve the beneficial diversity of wild relatives, genebanks play an important role as ex situ conversation sites (Dempewolf et al. 2014; Kilian et al. 2021). An overview of ex situ Triticum collections can be found in Sharma et al. 2021.

Due to wheat's role as a staple, the quality of the grain is of great importance. Its daily consumption in many parts of the world makes it a major source for calorie intake, but it also provides micronutrients and vitamins. Breeding for energy yield and grain quality for purposes such as baking has long been a major goal in wheat breeding and enabled food security for a growing population. However, the focus on micronutrients and allergenicity has only been a recent trend in wheat breeding. Especially in less diversified diets, a low concentration of micronutrients in wheat appears to be a major problem. This leads to micronutrient deficiencies ("hidden hunger"), especially for the crucial micronutrients iron (Fe) and zinc (Zn) (Graham et al. 2001, 2007; Johns and Eyzaguirre 2007). The main symptom of Fe deficiency is anemia, and $\mathrm{Zn}$ deficiency can affect growth and development (Prasad et al. 1961; Stein 2010; Gibson et al. 2010). To combat hidden hunger, one commonly used approach is biofortification (= enrichment of micronutrients) of crops (Johns and Eyzaguirre 2007). Crop biofortification can be achieved through agronomic strategies such as foliar fertilization or via various breeding methods such as introgression. Some wild relatives of wheat accumulate micronutrients very efficiently in the grain and offer high genetic diversity for this trait (Arora et al. 2019; Cakmak et al. 2000; Chhuneja et al. 2006; Chatzav et al. 2010). Therefore, they can be used as a breeding resource for biofortified crops (Cakmak et al. 2004; Rawat et al. 2009).

Wheat is consumed in various forms, for example as bread, pasta, bulgur and couscous. An important qualitydetermining characteristic is gluten, which comprises a group of seed storage proteins composed of glutenins and gliadins. While the former is very important for dough quality and elasticity, the latter is responsible for viscosity (Wieser 2007; Shewry 2019). However, gliadins can trigger an autoimmune disease called celiac disease (CD)
(Biesiekierski 2017). Currently, the only strategy for CD patients is to avoid wheat products. The wheat genepool may harbor diversity that can help to combine improved dough quality properties of glutenin with less toxic and non-immunogenic gliadin variants for $\mathrm{CD}$-safe wheat.

Phenolics are bioactive components in the grain with promising health benefits for the consumer (Laddomada et al. 2015). Phenolic compounds can be grouped into phenolic acids, flavonoids, stilbenes, coumarines, lignans and tannins. Phenolic acids are the most abundant component in wheat and are predominantly stored in the aleurone layer and the bran (Liyana-Pathirana and Shahidi 2006; Laddomada et al. 2015). The domesticated einkorn and emmer were assumed to be enriched in phenolic acid content (Serpen et al. 2008; Barański et al. 2020), and thus, wild wheats could be a valuable source for the enrichment of phenolic acids in the whole wheat grain.

This review provides an overview of the state of research on grain quality traits in the wheat genepool, including micronutrients, gluten and phenolics. Research on grain quality parameters in wheat relatives is summarized and assessed in the context of evolutionary history.

\section{The process of domestication}

Humans selected wild plants with favorable characteristics for cultivation and preparation to ensure food security. This process genetically transformed the plants into a domesticated plant that is dependent on human care and thus loses its ability to survive in the wild (Doebley et al. 2006). The modified plants showed a distinctive morphology that is referred to as the domestication syndrome (Hammer 1984). The domestication syndrome evolved from the selection of wild plants for higher germination rates and easier harvesting (Purugganan and Fuller 2009). The most common traits are the loss of seed shattering, increased seed size and alteration of the reproductive organs (Doebley et al. 2006; Ross-Ibarra et al. 2007; Meyer and Purugganan 2013). These domestication traits evolved through a combination of conscious and unconscious selection. Humans actively carried out conscious selection by selecting a favored trait and thus forwarded this trait into the next generation. Unconscious selection, on the other hand, favored the adaptability to the new agro-ecological environment shaped by human farming systems. As a result, the plant improved its performance in the field and was chosen for further breeding (Zohary 2004). In the beginning, wild and cultivated plants grew close to each other, which led to the exchange of genes via cross-pollination and gene flow (Gross and Olsen 2010; PrzewieslikAllen et al. 2021; He et al. 2019). This scenario still occurs today in the centers of origin of crops. However, human intervention has morphologically and genetically modified 
the wild plants, resulting in a newly domesticated species (Kantar et al. 2017). In addition to selection for domestication traits, selection for plant improvement further differentiated the domesticated species. This process is called diversification phase and involves the adaption of plants to new environments and selection for quality traits that differed individually for each crop (Meyer and Purugganan 2013). As a result, the differently pronounced selection pressure led to further divergence within the species. Genetic alteration and introduction into new habitats led to adaptation of a domesticated species. In summary, the domestication and improvement phase increased diversity in terms of the number of newly emerged domesticated taxa. However, it is important to focus on the initial situation of domestication. The onset of domestication occurred independently in different areas around the world at different times, but the traits of interest were similar (Purugganan and Fuller 2009; Meyer and Purugganan 2013). From the broad wild diversity that was available to humans, only a few plants were selected and used as founder crops (Ladizinsky 1985). Consistent cultivation and selection within these founder crops led to a genetic bottleneck that excluded many wild alleles from the domestication process (Doebley et al. 2006; Stetter et al. 2017). The diversity retrieved during the domestication and improvement phase cannot compensate for the reduced diversity at the beginning (Smýkal et al. 2018). The founder crop (population) experienced high selection pressure on domestication traits. Increased selection led to selective sweeps that are reflected in a reduced diversity of domestication loci compared to other loci (Smýkal et al. 2018; Maccaferri et al. 2019; Pont et al. 2019). Most early domesticates were annuals because the fixation of traits through an annual selection cycle was more successful and faster compared to perennials. Thus, selection pressure on desired traits accelerated the loss of diversity in the corresponding loci and reduced overall diversity (Maccaferri et al. 2019).

\section{Domestication history of wheat and its resulting diversity}

Wheat's allo-polyploidy accelerated its wider distribution, as polyploid species show a better adaption rate to new environments and outperform their ancestors with a lower degree of ploidy in agronomic traits (Dubcovsky and Dvorak 2007). Therefore, farmers favored them, which led to a larger cultivation area and facilitated their spread from the Fertile Crescent across the world.

\section{Diploid wheats}

Diploid wheats (AA) belong to the oldest cultivated plant species. Wild representatives of the diploid wheat group are Triticum boeoticum Boiss $(2 \mathrm{n}=2 \mathrm{x}=14, \mathrm{AA})$ and Triticum urartu Thumanjan ex Gandilyan $(2 \mathrm{n}=2 \mathrm{x}=14$, $\left.\mathrm{A}^{\mathrm{u}} \mathrm{A}^{\mathrm{u}}\right)$. Triticum monococcum $\mathrm{L}$. $(2 \mathrm{n}=2 \mathrm{x}=14$, $\mathrm{AA})$ is the domesticate of T. boeoticum. Together, they form the einkorn group of wheat. The Karacadağ and KartalKaradağ mountains in Turkey have been identified as their center of domestication (Heun 1997; Kilian et al. 2007b). From here, einkorn migrated east (Armenia, Georgia, Iran) and west via the Bosporus (Greece and toward Central Europe). Another route involved maritime transport to the Maghreb and the Iberian Peninsula. These routes are supported by archaeological evidence, but also the population structure of the einkorn genepool that was shaped by the migration routes (reviewed in: Zaharieva and Monneveux 2014; Brandolini et al. 2016) (Fig. 1).

T. urartu is phenotypically similar to T. boeoticum (Morrison 1993) but can be distinguished genetically (Yildirim and Akkaya 2006; Konovalov et al. 2010). T. urartu represents the A genome donor of tetra- and hexaploid wheats (Huang et al. 2002b; Yildirim and Akkaya 2006). T. urartu populations occur in the Fertile Crescent and are found in Lebanon, Turkey, Iraq, Iran and Transcaucasia. This geographic distribution also shaped the genetic diversity of $T$. urartu by forming groups according to bioclimatic and topographic criteria (Brunazzi et al. 2018).

\section{Tetraploid wheats}

Hybridization between $T$. urartu and a close relative of Aegilops speltoides Tausch $(2 \mathrm{n}=2 \mathrm{x}=14, \mathrm{BB} / \mathrm{GG})$, a member of the Sitopsis section in Aegilops, initiated the formation of the tetraploid wild wheat, $T$. dicoccoides. This wild emmer wheat further evolved into the domesticated T. dicoccon. However, the emmer lineage is not the only tetraploid wild wheat. Triticum araraticum Jakubz. $(2 \mathrm{n}=4 \mathrm{x}=28$, GGA ${ }^{\mathrm{u}} \mathrm{A}^{\mathrm{u}}$ ) is also a descendant of an independent hybridization between T. urartu and Ae. speltoides. Although both tetraploid wheat lineages share potentially the same parental species, they differ in the structure of the genome and time of origin (Adonina et al. 2015). Diversity analysis clearly showed a shared ancestry of Ae. speltoides and tetra- and hexaploid wheats. Ae. speltoides shared nuclear and cytoplasmic loci with $T$. dicoccoides and $T$. araraticum, which differed between the two wild tetraploid wheat species. Therefore, it was proposed that both genomes were derived (at least in parts) from Ae. speltoides as a maternal donor (Kilian et al. 2007a; Golovnina et al. 2007). However, the $\mathrm{G}$ genome of $T$. araraticum shows a closer relationship with Ae. speltoides, while the $\mathrm{B}$ genome donor is more distant to Ae. speltoides (Huang et al. 2002b; El Baidouri et al. 2017; Bernhardt et al. 2017). 


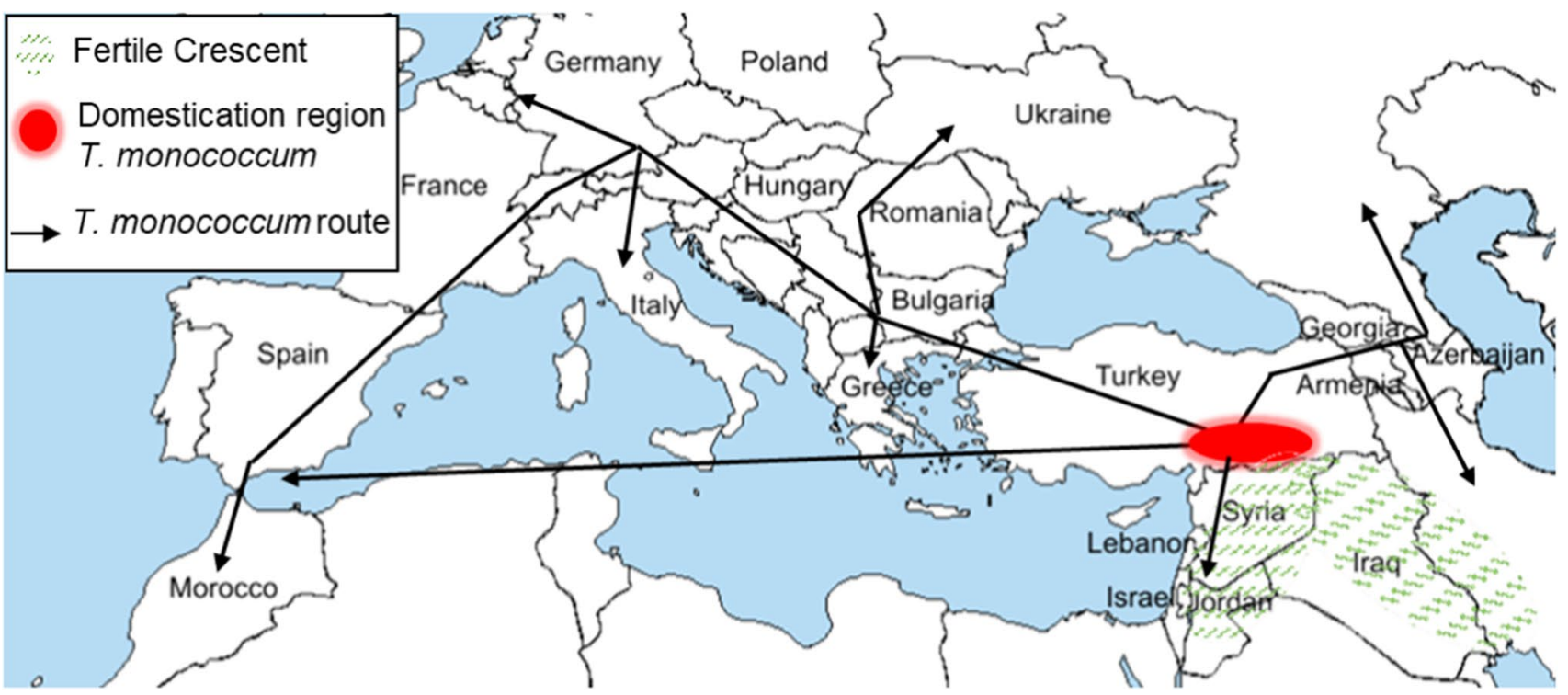

Fig. 1 Origin and spread of domesticated einkorn wheat T. monococcum. Green dashed fields represent the Fertile Crescent; red circle is the domestication region of T. monococcum (Heun 1997; Kilian et al.

\section{Domestication and cultivation of the BBAA lineage and the hexaploid BBAADD}

Molecular analysis of $T$. dicoccoides revealed two subgroups with distinct geographic origin. The southern Levant subgroup included genotypes from Israel, Palestine, Jordan, Syria and Lebanon. Accessions belonging to the other group were associated with the Central Eastern Fertile Crescent extending from Turkey to Iraq and Iran (Luo et al. 2007; Ozkan et al. 2005; Maccaferri et al. 2019). Some studies suggested a monophyletic origin of domesticated emmer from within the Central Eastern group. However, archaeological data indicate early cultivation of emmer in the Southern Levant (reviewed in: Özkan et al. 2011). Recent analysis suggested a multi-regional origin by showing that domesticated emmer contains alleles from both T. dicoccoides populations. It was concluded that wild emmer was pre-cultivated in the southern Levant and met wild emmer from the Central Eastern group through migration northwards, where it was eventually domesticated (Oliveira et al. 2020). T. dicoccon spread in all directions via various routes. Europe was reached via the Bosporus, the Balkans and the Iberian Peninsula. Africa was reached via the southern Levant and the Arabian Peninsula, and the spread to Asia was via Iran (reviewed in: Martínez-Moreno et al. 2020; Badaeva et al. 2015) (Fig. 2).

T. durum is currently the economically most important cultivated species from the tetraploid BBAA genepool. Durum wheat most likely originated in the eastern Mediterranean region (Luo et al. 2007; Kabbaj et al. 2017), which 2007b); arrows indicate T. monococcum's dispersal pathways (Zaharieva and Monneveux 2014; Brandolini et al. 2016)

is supported by a high genetic diversity in durum wheat accessions from the Central Fertile Crescent (Baloch et al. 2017). However, its evolution has not yet been fully elucidated. Phylogenetic analysis of wild and domesticated emmer, durum wheat landraces and durum cultivars revealed a close relationship between durum wheat landraces and domesticated emmer from the southern Levant. This suggests a rather linear evolution, in which increased selection and improvement on $T$. dicoccon facilitated the emergence of $T$. durum landraces. Moreover, modern durum wheat cultivars showed the closest relationship to durum wheat landraces from North Africa and Transcaucasia (Maccaferri et al. 2019). In contrast, exome sequencing data of the wheat genepool identified $T$. dicoccoides as a direct donor to $T$. dicoccon and $T$. durum, suggesting an entangled evolution (Pont et al. 2019). From its potential center of origin, durum wheat spread widely following similar expansion routes as T. dicoccon (Moragues et al. 2007; Kabbaj et al. 2017; Martínez-Moreno et al. 2020) (Fig. 2).

The emmer lineage evolved further via another hybridization event, which gave rise to the hexaploid wheats. Most likely, domesticated tetraploid wheat and Aegilops tauschii Cosson $(2 n=2 x=14$, DD) hybridized in the area of northeastern Iran and the southwestern Caspian Sea, giving rise to the hexaploid bread wheat, T. aestivum (Petersen et al. 2006; Salamini et al. 2002; Huang et al. 2002a; Pont et al. 2019). The highest genetic diversity for hexaploid bread wheat was found in the Near and Middle East, which is probably the center of diversity (Huang et al. 2002a). Hexaploid bread wheat is based on a founder race that further evolved into 


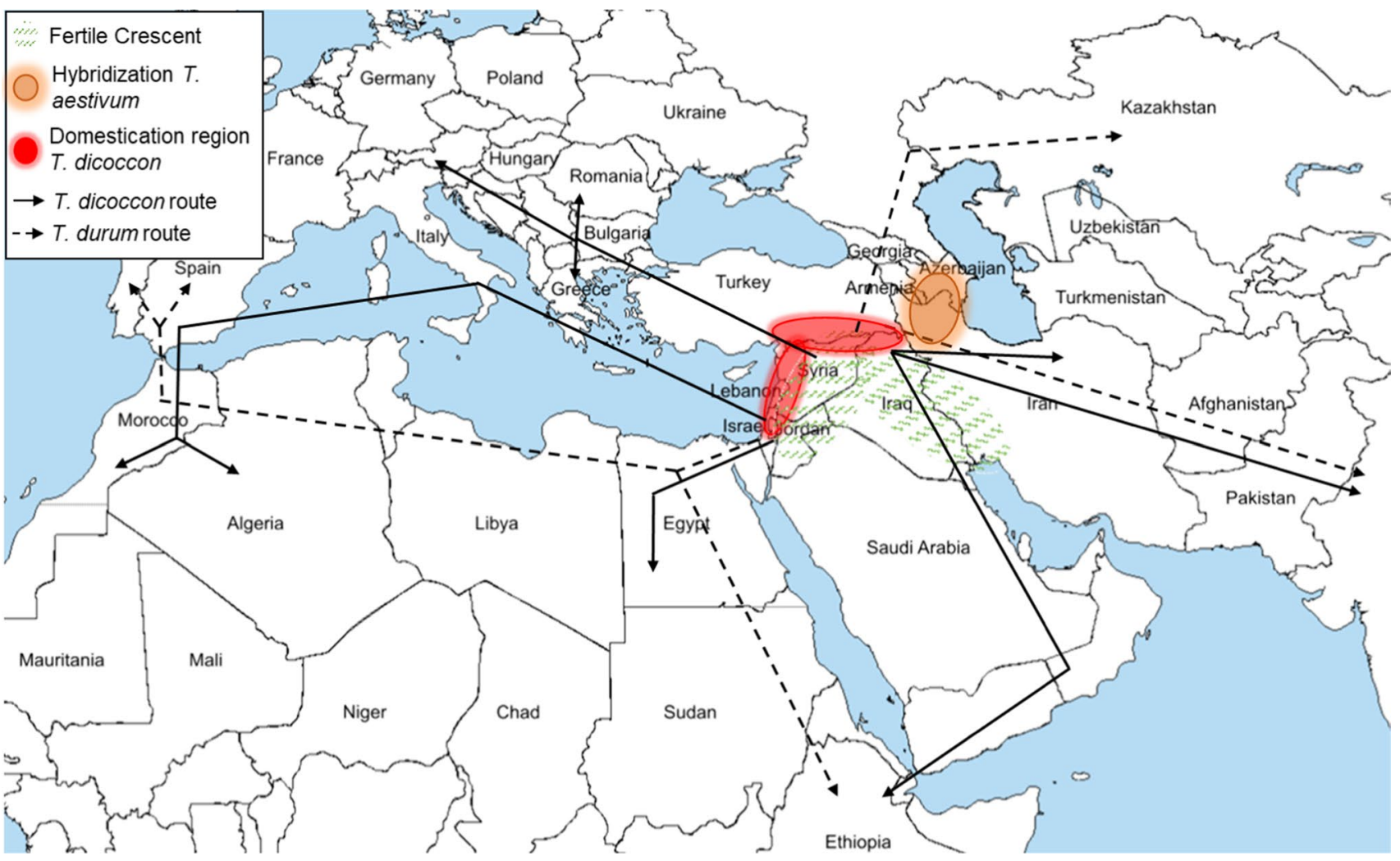

Fig. 2 Origin and spread of domesticated emmer and durum wheat. Green dashed fields are the Fertile Crescent; red circles are the domestication regions of $T$. dicoccon (Oliveira et al. 2020); solid arrows indicate dispersal routes of $T$. dicoccon (Martínez-Moreno et al. 2020; Badaeva et al. 2015); dashed arrows indicate dispersal route of T. durum (Moragues et al. 2007; Kabbaj et al. 2017; Martínez-Moreno et al. 2020); orange circle is the potential hybridization site of T. aestivum (Petersen et al. 2006; Salamini et al. 2002; Huang et al. 2002a; Pont et al. 2019)

T. araraticum comprises two subgroups. One subgroup (ARA-0) is widespread, while the other (ARA-1) was only found in south-eastern Turkey and north-western Syria (Badaeva et al. 2021).

Triticum timopheevii (Zhuk.) Zhuk $(2 \mathrm{x}=4 \mathrm{n}=28$, GGA ${ }^{\mathrm{u}} \mathrm{A}^{\mathrm{u}}$ ) is the domesticate of $T$. araraticum. The origin of T. timopheevii s.str. (found in Georgia) remains unclear, but was probably introduced from Turkey (Badaeva et al. 2021). Badaeva et al. (2021) also discuss the potential sister-group relationship between the Georgian T. timopheevii s.str. and the prehistoric and widespread T. timopheevii s.l. ('New Glume Wheat'), with the oldest known records being of Turkish origin.

The mixed cultivation of $T$. monococcum and T. timopheevii in western Georgia facilitated hybridization between the two. This event resulted in the hexaploid Triticum zhukovskyi Men. \& Er. $\left(2 n=6 x=42\right.$, GGA $\left.^{\mathrm{u}} \mathrm{A}^{\mathrm{u}} \mathrm{A}^{\mathrm{m}} \mathrm{A}^{\mathrm{m}}\right)$ (Badaeva et al., 1994; Badaeva et al., 2016; Badaeva et al., 2021) (Fig. 3). However, Pont et al. (2019) suggested a hybridization between $T$. araraticum and $T$. boeoticum for the formation of T. zhukovskyi. 
Fig. 3 Origin and spread of GGAA wheat. Green dashed fields are the Fertile Crescent; yellow circle indicates the center of diversity of $T$. araraticum (Gornicki et al. 2014; Badaeva et al. 2021); red circle is the domestication region of T. timopheevii (Mori et al. 2009; Badaeva et al. 2021); orange circle indicates the hybridization site of T. zhukovskyi (Badaeva et al. 1994; Badaeva et al. 2016; Badaeva et al. 2021)

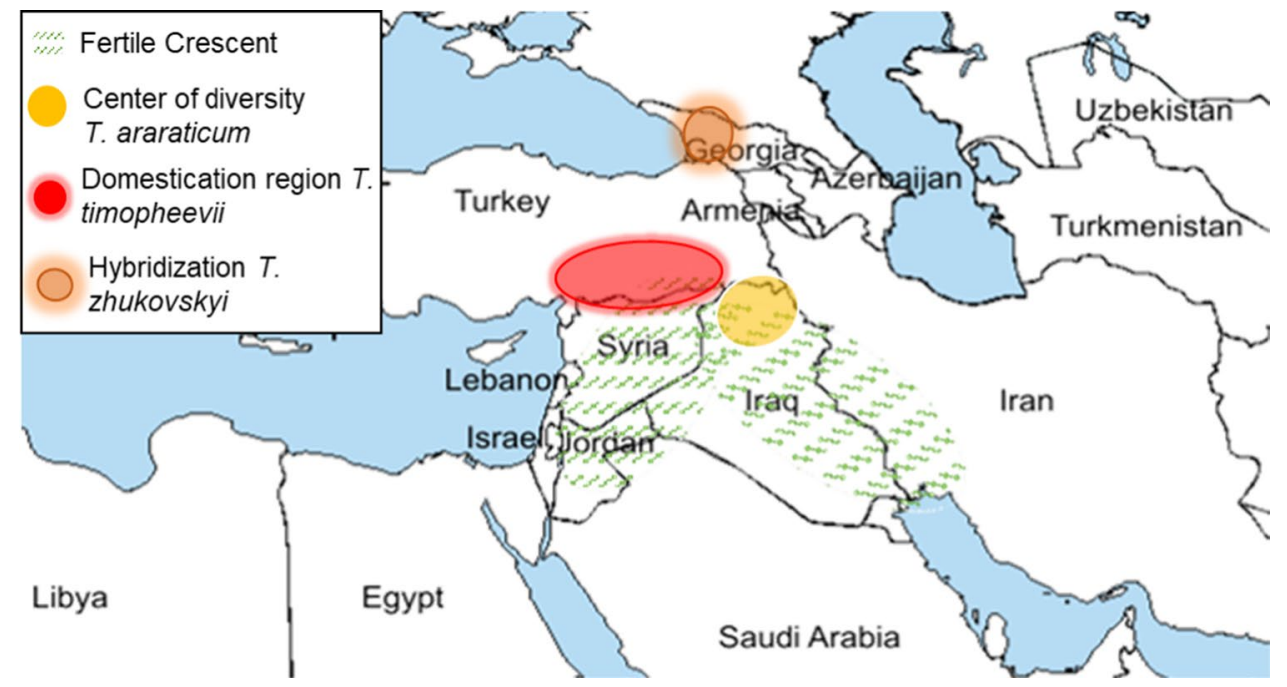

\section{Micronutrients in wheat wild relatives}

Iron $(\mathrm{Fe})$ and Zinc $(\mathrm{Zn})$ deficiency are major forms of micronutrient disorders in human diets relying on one major crop. Fe deficiency leads to anemia and insufficient $\mathrm{Zn}$ uptake impairs various essential functions of the body including growth, development and the immune system (Stein 2010). The large wheat genepool described earlier may harbor beneficial genetic variation for an increased accumulation of micronutrients in the edible parts of the wheat crop. Furthermore, the evolutionary pattern can be used to identify trends and underutilized species for biofortification.

\section{Wheat wild relatives show high enrichment and variation for $F e$ and $\mathrm{Zn}$ in the grain}

Aegilops species and the einkorn and emmer lineage were of interest for the grain micronutrient concentration and the variation. The wild species harbored a high variation for $\mathrm{Zn}$ grain concentration, whereas Aegilops species showed elevated Fe grain concentration.

Domesticated einkorn wheat forms a valuable source for biofortification, especially for Zn (Table 1) (Ozkan et al. 2007; Erba et al. 2011). In addition, high values of $\mathrm{Fe}$ and $\mathrm{Zn}$ were consistently found in T. monococcum accessions across different locations (Ozkan et al. 2007; Erba et al. 2011). Therefore, an underlying genetic component is likely. Compared to T. monococcum, the variation in $\mathrm{Zn}$ and Fe concentrations was higher in T. boeoticum in the studies comparing the wild and domesticated forms (Fig. 4, Table 1). This underlines the greater potential for genetic variation in crop wild relatives. Furthermore, grains of $T$. zhukovskyi could be potentially enriched in $\mathrm{Zn}$, due to the fact that it contains the A genome of T. monococcum. Among the few studies available, most focused on T. monococcum and T. boeoticum and excluded T. urartu, the actual A genome donor of emmer, durum, bread wheat and timopheevii wheat. Because of this ancestry, exploring the micronutrient content and accumulation of T. urartu might be valuable for the biofortification of its descendants. Diploid wheats have been less extensively investigated than their tetraploid relatives from the emmer lineage. One reason for this lack of interest could be their inferior agricultural performance or the challenges in introgressing beneficial alleles into bread wheat. Thus, there is still a research gap that needs to be explored.

The same is true for Aegilops accessions, which have been investigated only sporadically, although some accessions could be a promising resource for biofortification. Compared to cultivated bread wheat, Ae. tauschii and Ae. kotschyi showed higher grain $\mathrm{Fe}$ and $\mathrm{Zn}$ concentrations (Chhuneja et al. 2006; Rawat et al. 2009) (Table 1).

Tetraploid wild emmer wheat (T. dicoccoides) has always received attention as this species provides a valuable source of genetic variation in terms of accumulation of micronutrients (Table 1) (Cakmak et al. 2000; Peleg et al. 2008). Higher accumulation of $\mathrm{Fe}$ and $\mathrm{Zn}$ in $T$. dicoccoides compared to T. durum was also consistent under water deficient conditions (Peleg et al. 2008). Compared to modern wheat cultivars, wild emmer wheat showed a higher variation in $\mathrm{Zn}$ and Fe concentration (Cakmak et al. 2004). Comparing the variation between $\mathrm{Fe}$ and $\mathrm{Zn}$ in wild diploid $T$. boeoticum and wild tetraploid emmer wheat, the amplitude for $\mathrm{Zn}$ was higher than for $\mathrm{Fe}$ (Cakmak et al. 2000).

Studies that analyzed iron and/or zinc in wild wheat accessions were summarized to calculate an overall mean $(\mathrm{mg} / \mathrm{kg})$ (Table 1). Further, the mean value of species analyzed in at least two independent studies was used for comparison between species. Due to the small number of studies, the median and the individual values were visualized (Fig. 4) (Weissgerber et al. 2015). Aegilops accessions showed higher iron accumulation compared to Triticum taxa across different studies (Fig. 4). However, the highest value 


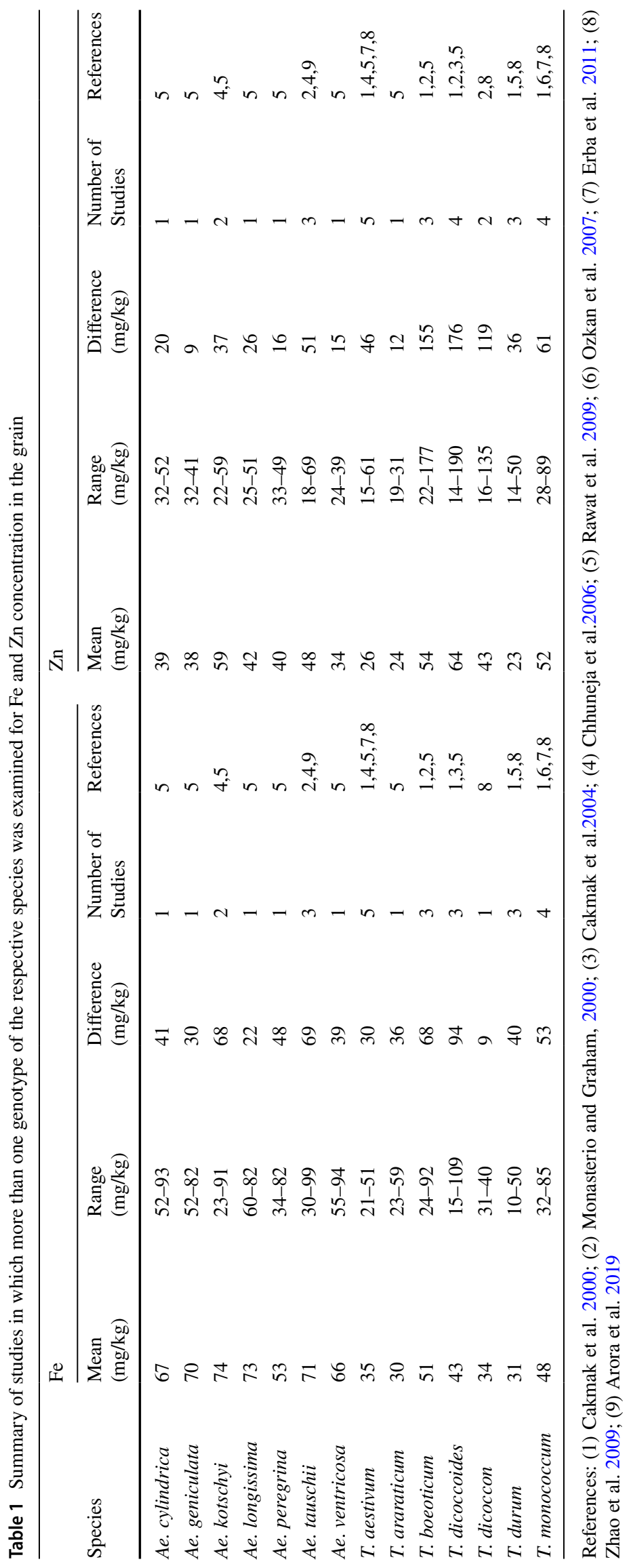



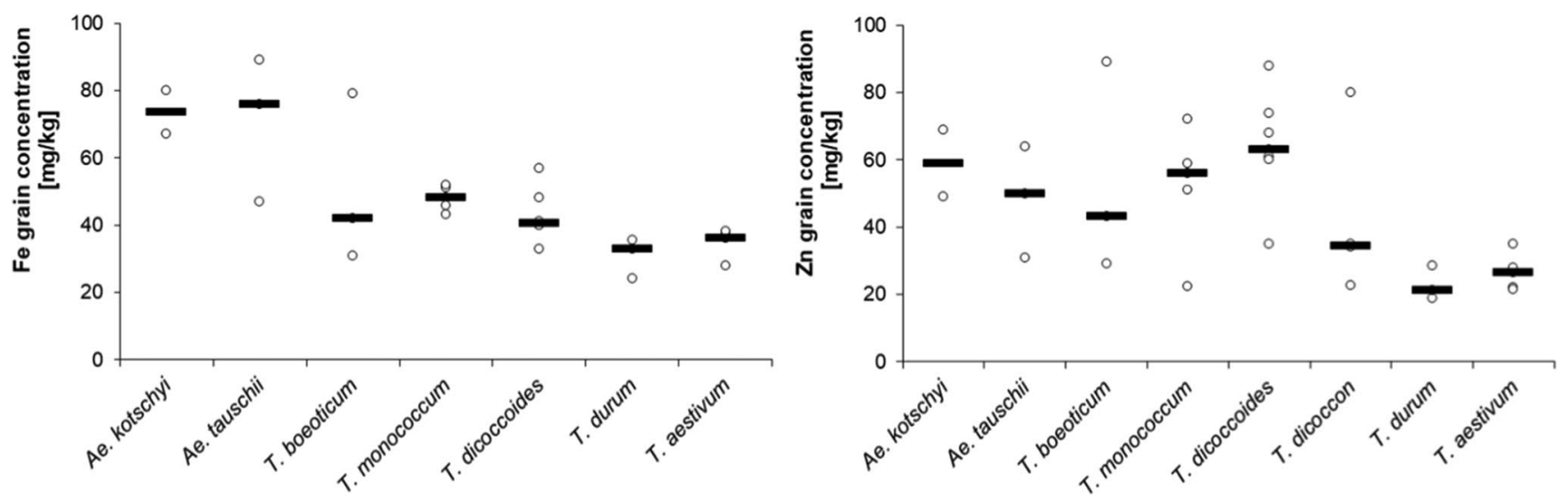

Fig. 4 Distribution of mean Fe or Zn grain concentration measured in different studies for different species. The bold lines are the median of different species means. Dots represent individual mean values. Excel script from Weissgerber et al. (2015)

for grain Fe concentration in T. boeoticum was in the same range as the median Fe concentration in Ae. kotschyi and Ae. tauschii. Such clear differentiation was not present for grain $\mathrm{Zn}$ concentration across species. The variation in grain Zn concentration was higher, as shown by the wider distribution of the mean values. This variation was pronounced in $T$. dicoccoides, which showed the highest median for grain Zn concentration (Fig. 4). This confirms the observations that the variation is higher for $\mathrm{Zn}$ accumulation than for $\mathrm{Fe}$. It is noteworthy that this enrichment and variation found in wild emmer has not been passed on and confirmed in its economically important progeny T. durum (Fig. 4).

\section{Factors influencing the Fe and $\mathrm{Zn}$ concentration in the grain}

How, if and to what extend the micronutrient concentration in the grain is influenced by external factors and the phenotype, e.g., grain size, is contradictory to date. Some authors argue that enhanced micronutrient density may come at the expense of agronomic performance. Progress in breeding for higher yields may have diluted the concentration of micronutrients in the grain, which is referred to as the dilution effect or reversible concentration effect in small grains (Cakmak et al. 2000). This hypothesis is supported by observations of negative correlations between yield and grain $\mathrm{Zn}$ concentrations (Oury et al. 2006). Negative correlation also occurred between the year of release of the respective variety and its micronutrient density (Zhao et al. 2009), suggesting that the breeding for high yield negatively affects micronutrient concentrations. This observation was more pronounced for $\mathrm{Zn}$ compared to Fe (Oury et al. 2006; Morgounov et al. 2007). On the other hand, some studies found no correlation between seed size and micronutrient concentration, calling into question the hypothesis of the dilution effect (Arora et al.
2019; Distelfeld et al. 2007). The micronutrient content per seed was analyzed in addition to the concentration. Seeds with the highest concentration also had the highest content per seed due to high seed weight and size (Cakmak et al. 2004, 2000). This clearly refutes the dilution hypothesis. In conclusion, the results concerning the relationship between agronomic performance and micronutrient density are controversial, suggesting that both components contribute to micronutrient density.

To identify the traits associated with grain micronutrient concentrations, correlations with other grain characteristics were analyzed. Agronomic management practices can help to increase micronutrient concentrations in the grain. Plants grown under nitrogen-sufficient conditions showed enriched micronutrients levels compared to nitrogen-deficient conditions (Monasterio and Graham 2000). Furthermore, higher grain protein content was also associated with higher micronutrients (Chatzav et al. 2010; Peleg et al. 2008). Fe and $\mathrm{Zn}$ are preferentially stored in the aleurone layer and the embryo. At the same time, the embryo contains high protein contents, which can explain the positive associations (Morgounov et al. 2007). As nutrients are translocated from the leaves to the grain during grain filling, nutrient concentrations ( $N, F e, \mathrm{Zn})$ in the flag leaf were correlated with grain concentrations (Rawat et al. 2009). These findings suggest that grain protein is a sink for micronutrients and explain why bread wheat shows lower micronutrient concentration than durum wheat (Cakmak et al. 2010). In conclusion, an adequate supply of nitrogen can help to exploit the full potential of micronutrient accumulation in the grain. However, there is also another genetic component that supports wild wheats in the enrichment of micronutrients in the grain. 


\section{Genetic properties of micronutrient accumulation in wheat wild relatives}

Micronutrient uptake and translocation are quantitatively controlled and inherited traits (Arora et al. 2019) that can be genetically dissected by genome mapping. Therefore, Recombinant Inbred Lines (RIL) from two domesticated einkorn lines were developed by Ozkan et al. (2007) in order to gain insights into the genetics of micronutrient uptake. They found a promising Quantitative Trait Loci (QTL) on the short arm of chromosome 5 that contributes micronutrient accumulation (Ozkan et al. 2007). Chromosome 5A also harbored favorable QTLs for Fe and Zn micronutrient concentrations in a tetraploid RIL population derived from durum wheat and wild emmer. The authors stated that the wild alleles increased micronutrient accumulation (Peleg et al. 2009). Furthermore, chromosome 6B was detected as a promising gene source conferring high micronutrient concentrations in grains (Peleg et al. 2009; Cakmak et al. 2000, 2004). RIL lines containing chromosome 6B of $T$. dicoccoides had an enriched $\mathrm{Zn}$ concentration in the grain (Cakmak et al. 2000, 2004). Independent of this finding, the QTL GPC-B1 on the short arm of chromosome 6B of $T$. dicoccoides was associated with elevated grain protein concentration (Joppa et al. 1997). GPC-B1 showed a direct influence on chlorophyll degradation of flag leaves, thus accelerating senescence, and had pleiotropic effects on grain protein (Uauy et al. 2006a). Consequently, the transportation mechanism of nitrogen from leaves to grains was investigated for its role in grain micronutrient content. Recombinant chromosome substitution lines carrying the $G P C-B 1$ allele from wild emmer wheat showed increased $\mathrm{Zn}$ and Fe concentration in the grain compared to the GPC-B1 allele from durum wheat (Distelfeld et al. 2007). The QTL was narrowed down to the allele $N A M-B 1$, which encodes a NAC transcription factor (Uauy et al. 2006b). Reduced expression of $N A M-B 1$ resulted in plants with lower levels of protein, $\mathrm{Zn}$ and $\mathrm{Fe}$ in the grain, but higher levels in the flag leaf. This proved the role of $N A M-B 1$ in remobilization of micronutrients and nitrogen (Uauy et al. 2006b) and further explained the observed positive correlation between these components described above. Only wild wheat species possessed the functional $N A M-B 1$ genes (GPC-B1 gene, used synonymously), leading to higher accumulation of micronutrients compared to T. durum and T. aestivum, where the allele is non-functional. Hexaploid wheat contains two functional homologous genes on chromosomes $6 \mathrm{~A}$ and $6 \mathrm{D}$ (Uauy et al. 2006b). This genetic alteration occurred during wheat evolution, emphasizing the benefit of wild relatives. Therefore, the genomes of wheat relatives were explored for similar loci. Orthologues of $N A M-B I$ were identified in T. timopheevii, Ae. speltoides, Ae. bicornis, Ae. longissima, Ae. searsii, and Ae. sharonensis (Hu 2012; Hu et al.
2013). Apart from some Single Nucleotide Polymorphisms (SNP), the T. timopheevii NAM-G1 orthologue resembled the $T$. dicoccoides $N A M-B 1$ gene in promoting grain protein content and was therefore considered as a putative target for micronutrient enrichment. However, the follow-up study by Hu et al. (2017) showed no association between NAMGl expression levels and grain $\mathrm{Fe}$ and $\mathrm{Zn}$ concentration. Consequently, they proposed a quantitatively controlled trait for micronutrient concentrations in grain rather than just $N A M-G 1$ as a single gene causing the higher micronutrient content (Hu et al. 2017). Another explanation for this finding could be that the allele does not function properly due to T. timopheevii's domestication status. To confirm this, a study with its wild ancestor T. araraticum would be required. Additionally, Ae. speltoides or an extinct close relative of it participated as donors for the B and G genome. However, different genoytpes were involved in the independent polyploidization events of the emmer and timopheevii lineage. Since the functional NAM gene is found on the B1 genome, it might be non-functional in G1, thus explaining the lower micronutrient concentration in T. timopheevii.

\section{Regulatory role of the GPC gene}

The physiological implications of this wild gene in hexaploid wheats were studied to elucidate its role in metal homeostasis. The pre- and post-anthesis phases are the most critical for micronutrient accumulation. Fe and $\mathrm{Zn}$ are not directly transferred into the grain. Initially, they are stored in the leaves, where they play an important role in the function of essential enzymes in mitochondria and plastids (Gupta et al. 2020). GPC is expressed during early senescence to prepare the plant for subsequent physiological processes (Cantu et al. 2011). Transcriptome analysis showed that under a high $G P C$ expression levels, genes involved in transport, protein metabolism and catabolic/catalytic processes are also induced (Cantu et al. 2011). To explain the highly efficient translocation of micronutrients from flag leaf to grain enabled by $G P C$, Fe and $\mathrm{Zn}$ transporters were analyzed under putative $G P C$ expression control. A Heavy Metal ATPase-like (HMA-like) was induced in the presence of GPC but was downregulated in $g p c$ knock out mutants. HMAs and HMA-like transporters enable the transfer of micronutrients from the chloroplast to the cytoplasm. From here, the released nutrients must reach the phloem. Genes from the ZIP family, which include transporters for $\mathrm{Fe}(\mathrm{IRT}=$ iron regulated transporter) and $\mathrm{Zn}(\mathrm{ZRT}=$ zinc regulated transporter), formed the majority of upregulated genes under GPC influence. For phloem transport, Fe and $\mathrm{Zn}$ must be chelated. In this context, a gene involved in the biosynthesis of the phytosiderophores (PS) nicotianamine (NA), nicotianamine aminotransferase (NAAT), was found at a higher level (Pearce et al. 2014) (Fig. 5). In line with this 


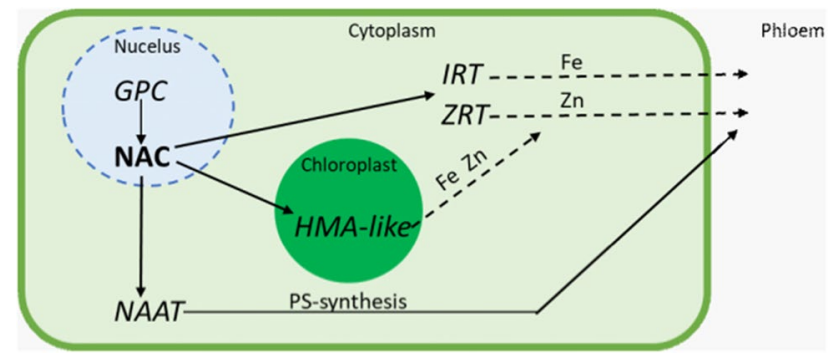

Fig. 5 Regulatory role of the $G P C$-encoded NAC transcription factor for micronutrient translocation. Bold arrows indicate regulated transporters; dashed arrows show the transport of micronutrients. $G P C=$ grain protein content gene; $\mathrm{NAC}=\mathrm{NAC}$ transcription factor; $I R T=$ iron-regulated transporter; $Z R T=$ zinc-regulated transporter; $H M A$-like $=$ Heavy Metal ATPase-like; $N A A T=$ nicotianamine aminotransferase; $\mathrm{PS}=$ phytosiderophores

finding, effective uptake and transportation via PS have also been suggested to be responsible for the higher micronutrient concentration in Aegilops species compared to Triticum species (Neelam et al. 2010). A genome-wide association study with the $\mathrm{D}$ genome donor Ae. tauschii confirmed the role of PSs by identifying marker-trait associations for iron concentrations. A significant locus was found near a gene involved in PS secretion (Arora et al. 2019). This shows that a subset of genes is controlled by the transcription factor encoding GPC gene, which facilitates the translocation of micronutrients. It is a unique example on how valuable wild alleles can be used for biofortification. However, since the GPC was not solely responsible for the accumulation of micronutrients in the grain, other genes need to be explored.

The identification of the functional GPC gene helps to understand the observed correlations between grain protein, yield and micronutrients explained above. First, it provides a plausible explanation for $T$. dicoccoides being such a promising source for higher grain micronutrient concentrations due to the functional $G P C-B 1$ allele. However, it remains unclear why there is such a high variation for $\mathrm{Zn}$ and $\mathrm{Fe}$ between $T$. dicoccoides accessions and how values as low as $15 \mathrm{mg} / \mathrm{kg}$ for $\mathrm{Fe}$ and $14 \mathrm{mg} / \mathrm{kg}$ for $\mathrm{Zn}$ can occur despite the presence of these functional alleles. One explanation could be a pronounced environmental influence, e.g., low micronutrient concentration in the soil. However, the wild GPC-BI alleles showed a stable contribution across different environments and no interaction between genotype and environment (Distelfeld et al. 2007). Either, these accessions lack the gene, perhaps due to adaption effects to different areas, or other genes associated with micronutrient accumulation may be equally important, which remain to be identified.

Second, the GPC gene might be involved in mechanisms leading to the dilution effect suggested earlier. Domesticated varieties contain functional orthologues of the $G P C$ allele only on the A and D genomes, which are less efficient in micronutrient translocation from the flag leaf to the grain than the copy on the B genome. Since the $G P C$-mediated translocation is more efficient for Fe than for $\mathrm{Zn}$ (Waters et al. 2009; Avni et al. 2014), the lower grain Zn concentration in modern varieties can be explained. However, as stated above $T$. dicoccoides shows a high variation for micronutrients. Assuming that only selected $T$. dicoccoides genotypes were domesticated, there might be a chance that the chosen ones were low accumulators and this trait has been passed on to the domesticates. Regarding a negative effect on yield, the results are contradictory. In a study with recombinant chromosome substitution lines of T. durum and T. dicoccoides, the functional GPC-BI allele did not affect yield (Distelfeld et al. 2007), while in another study a functional allele in hexaploid wheat led to reduced grain weights due to accelerated senescence (Waters et al. 2009). In conclusion, the wild $G P C-B 1$ allele appears to have a differential effect on different genotypes. When introducing this allele into modern varieties, the genotype-specific yield responses need to be taken into account.

It would be interesting to see if there is an underling geographical pattern indicating environmental factors that have shaped genetic variation enabling biofortification. The bioavailability of micronutrients in cereal grains is limited by phytate, which binds $\mathrm{Fe}$ and $\mathrm{Zn}$ in insoluble forms and thus makes them unavailable for humans. To date, there is a lack of studies reporting phytate data from wheat wild relatives, which should be addressed in future research along with micronutrient analyses. Overall, the wheat genepool is still poorly explored in terms of diploid species and the timopheevii lineage. These species need to be considered in future research projects. Some of the transport and accumulation pathways of micronutrients in wheat have already been identified. The underlying translocation mechanisms can be targeted in wheat wild relatives to identify mechanisms that can be used in the breeding of biofortified wheat.

\section{Gluten in wheat wild relatives}

Gluten is the main form of storage protein in the grain and determines the baking quality. Up to $90 \%$ of the protein in the seed are gluten. The gluten protein group includes two components, glutenins and gliadins, which differ in molecular weight and sulfur (S) content (Shewry 2019). Glutenins control dough strength and elasticity but make up only for $10 \%$ of the seed storage protein. These polymers are classified according to their molecular weight into low molecular weight glutenin subunit (LMW-GS) and high molecular weight glutenin subunit (HMW-GS). The latter is further subdivided into $\mathrm{x}$ and $\mathrm{y}$ HMW-GS. Gliadins are monomers comprising the S-rich prolamins $\alpha / \beta$ and $\gamma$ gliadins and the S-poor $\omega$-gliadins. Gliadins are responsible 
for the viscosity of the dough (Wieser 2007; Biesiekierski 2017; Shewry 2019). The gluten composition in the grain is strongly dependent on the genotype (Wieser 2007). Thus, different Triticum species show diversity for different quality and health properties.

\section{Wheat wild relatives harbor rare y-type high molecular weight glutenin subunits}

Glutenins are important for the baking quality of the flour and form the backbone of the gluten network. Glutenin content increases in the order of diploid $<$ tetraploid $<$ hexaploid wheats (Geisslitz et al. 2019). The Glul loci on the long arm of chromosome 1 homologous encode two HMW-GS genes, the $\mathrm{x}$ - and y-type subunits (Li et al. 2020b; Payne et al. 1980, 1984). The former has a higher molecular weight than the latter. HMW-GS that originate from the D genome influence dough properties the most (Li et al. 2020b). However, y-type subunits are also important for dough quality, although the $\mathrm{y}$-subunit of the A genome (1Ay) is usually not expressed in hexaploid bread wheat (Waines and Payne 1987). Due to the higher number in cysteine residues compared to the $\mathrm{x}$-subunit, the $\mathrm{y}$-subunit is a valuable source for increasing dough quality (Li et al. 2020b).

The variation in HMW-GS decreased with increasing ploidy status during evolution (Xu et al. 2009). The diploid wheat species showed the highest variation in molecules encoding the 1 Ay subunit (Hu et al. 2012). The diploid A genome donor of wheat $T$. urartu contained different $1 \mathrm{Ay}$ subunit variants (Xu et al. 2009; Caballero et al. 2008; Hu et al. 2010). However, not all 1Ay subunits were expressed (Xu et al. 2009). This pattern was especially found in T. urartu accessions from Turkey, Armenia, Iraq and Iran (Waines and Payne 1987). Yet, the variation for 1Ay subunits was characterized by a rare allelic distribution (Caballero et al. 2008). Prediction of the secondary structure of the 1 Ay subunit of $T$. urartu showed a potentially beneficial structure for flour processing quality (Hu et al. 2010). T. boeoticum may be another source of 1 Ay subunit introduction (Waines and Payne 1987). The 1Ay subunit encoded by this species was different from the expressed 1Ay subunit of T. urartu (Hu et al. 2012; Jiang et al. 2009). The 1 Ay subunit of T. boeoticum had a higher molecular mass and was thus longer, which favors the formation of an enhanced gluten network due to interchain bonds (Jiang et al. 2009). Introgression of the Glu-Al locus of T. boeoticum into bread wheat resulted in an improved dough quality (Rogers et al. 1997). The domesticated einkorn T. monococcum contained functional 1 Ay subunits, two of which were investigated for their molecular characterization (Guo et al. 2013). One allelic variant showed an additional cysteine residue, which could improve dough quality (Guo et al. 2013). The diversity of 1 Ay subunits was higher in T. boeoticum and
T. monococcum than in T. urartu (Hu et al. 2012). Thus, the diploid wheats contain useful diversity for enriching dough quality, which should be exploited.

T. dicoccoides contained the highest variation in $1 \mathrm{Ay}$ subunits among the tetraploid wheat species (Hu et al. 2012). An active 1Ay subunit in T. dicoccoides (GenBank accession: JF519636) resembled the pattern of amino acid sequences of the 1 Ay gene found in T. urartu, but they differed in their predicted secondary protein structure (Bi et al. 2014). However, in a phylogenic analysis, this 1 Ay allele of $T$. dicoccoides clustered together with another $T$. dicoccoides 1 Ay subunit (GenBank accession: KC545956). This in turn was introgressed into hexaploid wheat and positively associated with improved dough quality (Wang et al. 2018). The former subunit allele (JF519636) and probably other active 1 Ay alleles of $T$. dicoccoides thus harbor putative beneficial quality traits.

The wild tetraploid counterpart $T$. araraticum in the GGAA lineage showed only three different 1 Ay subunits (Hu et al. 2012). Two of these 1Ay subunits were similar to $T$. boeoticum, and three were similar to T. monococccum (Hu et al. 2012). In T. timopheevii, only one 1 Ay subunit was found that matched a subunit from T. monococcum (Wan et al. 2002; Hu et al. 2012). This variant also occurred in T. zhukovskyi. The other variant of the hexaploid $\mathrm{GGA}^{\mathrm{u}} \mathrm{A}^{\mathrm{u}} \mathrm{A}-$ ${ }^{\mathrm{m}} \mathrm{A}^{\mathrm{m}}$ T. zhukovskyi taxon did not occur in one of its putative ancestors (Hu et al. 2012). The variant $1 \mathrm{Ay} 8$ subunit in T. monococcum was favorable for bread making quality (Guo et al. 2013). T. araraticum contained the homologous $1 \mathrm{By} 8$ subunit (Hu et al. 2012), which could make T. araraticum a potential source for quality improvement.

Wheat wild relatives show valuable y-type HMW-GS that promise improved dough quality. In particular, all diploid ancestors harbor favorable variants. The less explored GGAA lineage and especially $T$. zhukovskyi may be a valuable source for y-type subunits due to its kinship with both diploid A-genome wheat species, T. urartu and T. monococcum. This is also an advantage over the BBAA and BBAADD wheat species. As the diversity of the active $1 \mathrm{Ay}$ subunits decreased during wheat evolution and domestication history, it is of great importance to conserve the wild relatives.

\section{Alpha-gliadins in wild wheat-a safe option for celiac disease patients?}

The monomeric gliadins comprise a large gene family with high diversity due to their long evolutionary history. The Gli locus comprises genes that encode for gliadins. $\omega$ and $\gamma$ gliadins are encoded by the Glil locus on chromosome 1 homologous. The short arm of chromosome 6 homologues contains the Gli2 locus, which encodes $\alpha / \beta$ gliadins (Payne 1986). In addition to its quality-determining properties, 
gluten has a negative effect on patients with celiac disease (CD). The primary trigger for $\mathrm{CD}$ are $\alpha$-gliadins, whereas the other gliadin groups appear to be less harmful but not entirely safe for some CD patients (Biesiekierski 2017). In the small intestine, gluten is digested (deamidated) and epitopes are formed during this process. These epitopes confer a $\mathrm{T}$ cell response that is activated by $H L A-D Q 2$ and -DQ8 (HLA = Human leukocyte antigen) and leads to an autoimmune response (reviewed in: Biesiekierski 2017). Alpha-gliadins containing the 33 mer peptide are most likely to cause $\mathrm{CD}$. The $33 \mathrm{mer}$ peptide comprises the epitopes DQ2.5-glia- $\alpha 1 \mathrm{a}$ and $b$, DQ2.5-glia- $\alpha 2$ and DQ2.5-glia- $\alpha 3$. The immunodominant 33 mer fragment originates from the D genome (Schaart et al. 2020). Therefore, diploid and tetraploid wheats might confer a less toxic immune response.

Domesticated einkorn T. monococcum contained more gliadin and thus more gluten than common wheat. This observation was consistent across different locations, leading to the assumption that the higher gluten and gliadin are a characteristic of einkorn wheat (Geisslitz et al. 2019). It is noteworthy that $T$. boeoticum, the wild ancestor of T. monococcum, showed higher gliadin content compared to its domesticate (Ozuna and Barro 2018). However, at the molecular level, T. urartu and T. monococcum lacked some of the toxic epitopes and thus the 33 mer peptide (Molberg et al. 2005; Salentijn et al. 2009; Zhang et al. 2015; van Herpen et al. 2006; Ozuna and Barro 2018). Spaenij-Dekking et al. (2005) also found less alpha-gliadins in diploid A genomes. A comparative toxicity study suggested that gliadin of T. monococcum would be safer for CD patients than gliadin from T. aestivum (Pizzuti et al. 2006). However, T. monococcum harbors many different, putatively immunogenic and toxic epitopes; thus, it cannot be considered a CDsafe food only because of the absence of a 33 mer peptide (Vaccino et al. 2009; Ozuna et al. 2015). The same is true for T. urartu, which lacks the DQ2.5-glia- $\alpha 2$ epitope, but contains DQ2.5-glia- $\alpha 1 \mathrm{a}$ and DQ2.5-glia- $\alpha 3$ CD-triggering epitopes (Zhang et al. 2015; Ruiz-Carnicer et al. 2019). This implies that regarding the quantity and molecular composition of gluten, einkorn is not a safe option for CD patients.

Compared to einkorn, emmer wheat contained less gliadin and gluten, but more than hexaploid bread wheat (Geisslitz et al. 2019). The potential B/G genome donor Ae. speltoides also lacked the 33 mer peptide (Molberg et al. 2005; Schalk et al. 2017), and conclusively, some of the T. dicoccon and T. durum samples showed the same phenotype (Molberg et al. 2005). The B genome in tetraploid and hexaploid wheat showed the lowest expression level compared to Gli A2 and Gli D2 (Salentijn et al. 2009). Further, it harbored the lowest amount of toxic epitopes (Ozuna et al. 2015). Indeed, Ae. speltoides, Ae. longissima and Ae. searsii showed no abundance of any of the canonical epitopes (Ruiz-Carnicer et al. 2019). However, genes encoding for $\alpha$-gliadins in $T$. dicoccoides encode toxic epitopes and thus constitute a threat for CD patients ( $\mathrm{Qi}$ et al. 2006, van den Broeck et al. 2010, Ozuna and Barro 2018). However, the CD-triggering $\alpha$-gliadin epitopes are most likely retrieved from the A genome (van den Broeck et al. 2010). Alpha-gliadins from the A genome in T. dicoccoides contained the T cell epitopes DQ2.5-glia- $\alpha 1 \mathrm{a}$ and DQ2.5-glia- $\alpha 3$, which resembles the pattern in T. urartu (Huo et al. 2019; Zhang et al. 2015). In summary, the B genome of tetraploid wheats can be considered the least toxic, but due to the presence of the A genome, tetraploid wheats remain unsuitable for $\mathrm{CD}$ patients. However, the content of toxic epitopes varied in tetraploid wheat and decreased as domestication progressed (van den Broeck et al. 2010; Ozuna and Barro 2018). Thus, domesticated species seem to be more suitable for breeding wheat with fewer CD-triggering epitopes. It has to be kept in mind that this approach will generally only help a part of the CD patients, as the variability of toxic epitopes is high and the response to these depends on the individual.

Ae. tauschii formed all of the three harmful epitopes. The DQ2.5-glia- $\alpha 2$ and DQ2.5-glia- $\alpha 1$ b epitopes were exclusively assigned to the D genome and were only found in hexaploid wheat, suggesting that this epitope was inherited via the D genome donor (Ruiz-Carnicer et al. 2019; Ozuna and Barro 2018). Ae. tauschii showed a high diversity for unique $\alpha$-gliadin peptide variants, but only accessions from the potential geographic origin of hexaploid wheat hybridization (south-west Caspian Sea) contained the toxic 33 mer peptide. On the one hand, this suggests that the CD-triggering epitope in bread wheat originates from this geographic region, but on the other hand, it also underlines that there are many Ae. tauschii accessions which might contain less to no toxic peptide variants (Schaart et al. 2020).

The 33 mer peptide is the main trigger of CD; however, it seems that even partial epitopes can already cause a reaction in $\mathrm{CD}$ patients. Regarding the abundance of canonical epitopes, the $\mathrm{D}$ genome donor seems to show the highest profusion, followed by BAD and the A genome donor. The $\mathrm{B}$ genome is the least harmful in terms of toxic epitopes (Ruiz-Carnicer et al. 2019). It is still unclear whether the $\mathrm{G}$ genome has less toxic $\alpha$-gliadins to offer, but the timopheevii lineage does not seem to be a promising resource for low $\alpha$-gliadin epitopes, as the tetraploid T. araraticum and T. timopheevii potentially have the same A genome donor species as the emmer lineage. Moreover, $T$. zhukovskyi is probably even worse because the A genomes of T. urartu and T. monococcum are present. Nevertheless, one has to consider that the most toxic 33mer peptide comes from the $\mathrm{D}$ genome, which is absent in the timopheevii lineage. Therefore, it might be worthwhile to identify other epitopes there. 


\section{Phenolic acids in the wheat genepool}

Phenolics occur in free, soluble conjugated and insoluble bound forms, with the latter form being the most abundant (Adom and Liu 2002). The differently bound phenolic acids differ in their bioavailability (Laddomada et al. 2015). Ferulic acid is the major phenolic acid found in wheat (Hernández et al. 2011), and it follows the pattern of the free, soluble conjugated and insoluble bound phenolics at a ratio of 0.1:1:100 (Adom and Liu 2002). Wheat relatives have been investigated for their content in phenolic acids due to their antioxidant capacity.

Data on the phenolics content of wild wheats are rare and contradictory. The wild diploid wheats T. urartu and T. boeoticum showed higher total polyphenol content (TPC) compared to the domesticated T. monococcum, T. dicoccon and T. aestivum, in which TPCs were almost the same (Brandolini et al. 2015; Yilmaz et al. 2015), while $T$. durum grouped in between (Brandolini et al. 2015). The wild tetraploid emmer revealed the lowest phenolic content among domesticated emmer, T. durum and other tetraploid emmer landraces, thus implying inferiority of phenolic content of the wild ancestor of the tetraploid wheats (Laddomada et al. 2017). Some data are available for the domesticated einkorn and emmer. Emmer showed a higher total phenolic content compared to einkorn, which was even lower than the total phenolic content of bread wheat (Serpen et al. 2008). This pattern was also found in the ferulic acid content (Serpen et al. 2008). The opposite was reported by Barański et al. (2020), who measured significantly higher total phenolic acids in einkorn compared to emmer. However, this study only contained one einkorn line (Barański et al. 2020). Both studies revealed contradictory result compared to the equal phenolic content of emmer and einkorn reported by Brandolini et al. (2015). A summary of studies analyzing T. monococcum, T. dicoccon, T. durum and T. aestivum with the same method and an overall comparison of studies with different methods were compiled by Shewry and Hey (2015). In the former comparison, einkorn ranked last in the total phenolic acid and ferulic acid content and emmer ranked first, also showing a high variation. In their comparison of different studies, the authors found no distinct differences in the phenolics content across species due to high variability (Shewry and Hey 2015).

In conclusion, no clear pattern can be identified from those studies. This might also be due to different analytical methods applied (Shewry and Hey 2015). Hence, there is no clear evidence that wild wheats possess valuable characteristics for the improvement in phenolic contents in wheat.
The grain quality in an evolutionary context

Evolution describes the gradual process of change and development in populations over time. Thereby, new characteristics or traits develop or disappear. The discussed grain quality characteristics micronutrients and gluten indicate an evolutionary pattern in their variation and accumulation. The main drivers for this phenomenon were a transition from wild to domesticated species and the change in ploidy levels. First of all, the variation for $\mathrm{Fe} /$ $\mathrm{Zn}$ and $1 \mathrm{Ay}$-glutenin subunits was higher in wild relatives of wheat compared to the domesticated species (Table 1, Fig. 4) (Cakmak et al. 2000, 2004; Peleg et al. 2008; Hu et al. 2012). This implies that during the transformation from wild to cultivated species, those traits were unintentionally altered and fixed, thus reducing the resulting diversity. However, the process of domestication also contributed to more stable grain quality traits, which is especially important for the baking quality. Besides the variation, the level of accumulation of $\mathrm{Fe}$ and $\mathrm{Zn}$ and $\alpha$-gliadins also showed an evolutionary trend. The domesticated species harbored lower accumulation potential than the wild relatives. In the case of micronutrients, the gene $G P C-B 1$, which turned non-functional during emmer domestication, underlies this phenomenon (Uauy et al. 2006b). High variation and accumulation potential for these grain constituents are thus features of wheat wild relatives that could be exploited in wheat improvement. In the case of phenolics, neither a clear pattern for changes in variation nor for an enrichment of phenolic content in wild and domesticated wheats was identified due to the lack of studies. However, it seems that there might be no evolutionary pattern for this secondary metabolite. Another evolutionary phenomenon that may have affected grain quality is allopolyploidization. The change in ploidy status caused different patterns for gliadin and glutenin during evolution: while an increase in ploidy reduced the gliadin content, the opposite was true for glutenin (Geisslitz et al. 2019).

Due to a lack of information in the scientific literature, the neglected timopheevii lineage should be analyzed regarding its grain quality. As with other wild species, the wild $T$. araraticum would be expected to exhibit high variations in $\mathrm{Fe}$ and $\mathrm{Zn}$. Similar $\alpha$-gliadin derived epitopes were found in $T$. urartu and $T$. dicoccoides and were both obtained from the A genome. Those epitopes would be likely to occur in the timopheevii lineage due to its ancestry with T. urartu, and furthermore, T. zhukovskyi might additionally contain the epitopes from $T$. monococcum. However, the toxic 33mer peptide is less likely to be represented in this lineage because of the missing hybridization with Ae. tauschii. Wild T. araraticum could also be a potential source for variation for glutenin subunits, 
but higher glutenin concentration would be expected in the domesticated tetra- and hexaploid species due to their polyploidization status. These assumptions need scientific evidence, but if they hold true, they could support the concept that evolutionary history can help to identify beneficial species.

\section{Conclusion}

The wild relatives of wheat harbor a large genetic diversity for certain grain quality traits such as minerals or gluten content. Additional important grain quality traits such as starch composition, fatty acid composition and non-starch polysaccharide concentration in wheat wild relatives have barely been investigated in the past. Thus, exploring the variation in these compounds in the wild relatives could be interesting topics for future studies. So far, the focus of most quality traits research has been on $T$. dicoccoides because of its straightforward use in bread wheat improvement. Identification of the underlying causative loci and polymorphism can be difficult in wild relatives due to the lack of reference genome sequences. However, ongoing advances in sequencing technology can simplify the development of reference genomes sequences for wheat wild relatives (Avni et al. 2017; Maccaferri et al. 2019; Ling et al. 2018; Walkowiak et al. 2020; Luo et al. 2017; Pont et al. 2019). In addition, the development of a wheat pan-genome sequence can be a valuable strategy in harnessing the genetic diversity of wheat wild relatives (Khan et al. 2020). Furthermore, the advent of genome editing enables de novo domestication strategies for targeted use of crop wild relatives (Fernie and Yan 2019; Zsögön et al. 2017, 2018; Xie and Liu 2021). However, ex situ conservation in genebanks constitutes an important strategy for safeguarding this unexplored diversity and also provides useful information/passport data of the accessions (https://www.genesys-pgr.org). In this context, the diploid taxa should receive more attention, due to their potential for enhancing grain micronutrient concentration as well as y-type HMW-GS. The same applies to the neglected GGAA lineage of wheat, in which quality traits remain to be investigated. In conclusion, further exploring the extended wheat gene pool harbors great potential for wheat diversification and quality improvement.

Online Resource Map: https://de.m.wikipedia.org/wiki/ Datei:A_large_blank_world_map_with_oceans_marked_ in_blue.PNG.

Acknowledgements This work was supported by a $\mathrm{PhD}$ scholarship from the Studienstiftung des deutschen Volkes (FZ). B.K. thanks the Government of Norway (QZA-14/0005) for funding the initiative "Adapting Agriculture to Climate Change: Collecting, Protecting and
Preparing Crop Wild Relatives" (https://www.cwrdiversity.org/proje ct/pre-breeding/).

Authors' contribution statement FZ compiled and analyzed the reviewed literature and data, structured and wrote the manuscript, and created the figures and table. BK contributed and edited the manuscript. MF contributed and edited the manuscript.

Funding Open Access funding enabled and organized by Projekt DEAL. This work was supported by Institute of Agronomy and Plant Breeding I core funding and the Crop Wild Relatives Project (Adapting Agriculture to Climate Change: Collecting, Protecting and Preparing Crop Wild Relatives), which is supported by the Government of Norway and managed by the Global Crop Diversity Trust [https://www. cwrdiversity.org/]. Moreover, FZ received a $\mathrm{PhD}$ scholarship from Studienstiftung des deutschen Volkes.

\section{Declarations}

Conflicts of interest The authors declare that they have no conflict of interest.

Ethics approval. The authors declare that the experiments comply with the current laws of Germany.

Open Access This article is licensed under a Creative Commons Attribution 4.0 International License, which permits use, sharing, adaptation, distribution and reproduction in any medium or format, as long as you give appropriate credit to the original author(s) and the source, provide a link to the Creative Commons licence, and indicate if changes were made. The images or other third party material in this article are included in the article's Creative Commons licence, unless indicated otherwise in a credit line to the material. If material is not included in the article's Creative Commons licence and your intended use is not permitted by statutory regulation or exceeds the permitted use, you will need to obtain permission directly from the copyright holder. To view a copy of this licence, visit http://creativecommons.org/licenses/by/4.0/.

\section{References}

Adonina IG, Goncharov NP, Badaeva ED, Sergeeva EM, Petrash NV, Salina EA (2015) (GAA)n microsatellite as an indicator of the A genome reorganization during wheat evolution and domestication. Comparative Cytogenetics 9(4):533-547. https://doi.org/10. 3897/CompCytogen.v9i4.5120

Adom KK, Liu RH (2002) Antioxidant activity of grains. J Agric Food Chem 50(21):6182-6187. https://doi.org/10.1021/jf0205099

Arora S, Cheema J, Poland J, Uauy C, Chhuneja P (2019) Genomewide association mapping of grain micronutrients concentration in aegilops tauschii. Front Plant Sci 10:54. https://doi.org/10. 3389/fpls.2019.00054

Avni R, Nave M, Barad O, Baruch K, Twardziok SO, Gundlach H, Hale I, Mascher M, Spannagl M, Wiebe K, Jordan KW, Golan G, Deek J, Ben-Zvi B, Ben-Zvi G, Himmelbach A, MacLachlan RP, Sharpe AG, Fritz A, Ben-David R, Budak H, Fahima T, Korol A, Faris JD, Hernandez A, Mikel MA, Levy AA, Steffenson B, Maccaferri M, Tuberosa R, Cattivelli L, Faccioli P, Ceriotti A, Kashkush K, Pourkheirandish M, Komatsuda T, Eilam T, Sela H, Sharon A, Ohad N, Chamovitz DA, Mayer KFX, Stein N, Ronen G, Peleg Z, Pozniak CJ, Akhunov ED, Distelfeld A (2017) Wild emmer genome architecture and diversity elucidate 
wheat evolution and domestication. Science (New York, NY) 357(6346):93-97. https://doi.org/10.1126/science.aan0032

Avni R, Zhao R, Pearce S, Jun Y, Uauy C, Tabbita F, Fahima T, Slade A, Dubcovsky J, Distelfeld A (2014) Functional characterization of GPC-1 genes in hexaploid wheat. Planta 239(2):313-324. https://doi.org/10.1007/s00425-013-1977-y

Badaeva ED, Keilwagen J, Knüpffer H, Waßermann L, Dedkova OS, Mitrofanova OP, Kovaleva ON, Liapunova OA, Pukhalskiy VA, Özkan H, Graner A, Willcox G, Kilian B (2015) Chromosomal passports provide new insights into diffusion of emmer wheat. PLoS ONE 10(5):e0128556. https://doi.org/10.1371/journal. pone. 0128556

Badaeva ED, Konovalov FA, Knüpffer H, Fricano A, Ruban AS, Kehel Z, Zoshchuk SA, Surzhikov SA, Neumann K, Graner A, Hammer K, Filatenko A, Bogaard A, Jones G, Özkan H, Kilian B (2021) Genetic diversity, distribution and domestication history of the neglected GGA t A t genepool of wheat

Baloch FS, Alsaleh A, Shahid MQ, Çiftçi V, Sáenz E, de Miera L, Aasim M, Nadeem MA, Aktaş H, Özkan H, Hatipoğlu R (2017) A Whole genome DArTseq and SNP analysis for genetic diversity assessment in durum wheat from central fertile crescent. PLoS ONE 12(1):e0167821. https://doi.org/10.1371/journal. pone. 0167821

Barański M, Lacko-Bartošová M, Rembiałkowska E, Lacko-Bartošová L (2020) The effect of species and cultivation year on phenolic acids content in ancient wheat. Agronomy 10(5):673. https://doi. org/10.3390/agronomy 10050673

Bernhardt N, Brassac J, Kilian B, Blattner FR (2017) Dated tribe-wide whole chloroplast genome phylogeny indicates recurrent hybridizations within Triticeae. BMC Evol Biol 17(1):141. https://doi. org/10.1186/s12862-017-0989-9

Bi Z-G, Wu B-H, Hu X-G, Guo X-H, Liu D-C, Zheng Y-L (2014) Identification of an active 1Ay gene from Triticum turgidum ssp. dicoccoides. Czech J Genet Plant Breed. 50:208-215. https://doi. org/10.17221/195/2012-CJGPB

Biesiekierski JR (2017) What is gluten? J Gastroenterol Hepatol 32(Suppl 1):78-81. https://doi.org/10.1111/jgh.13703

Brandolini A, Hidalgo A, Gabriele S, Heun M (2015) Chemical composition of wild and feral diploid wheats and their bearing on domesticated wheats. J Cereal Sci 63:122-127. https://doi.org/ 10.1016/j.jcs.2015.03.005

Brandolini A, Volante A, Heun M (2016) Geographic differentiation of domesticated einkorn wheat and possible Neolithic migration routes. Heredity 117(3):135-141. https://doi.org/10.1038/ hdy. 2016.32

Brozynska M, Furtado A, Henry RJ (2016) Genomics of crop wild relatives: expanding the gene pool for crop improvement. Plant Biotechnol J 14(4):1070-1085. https://doi.org/10.1111/pbi.12454

Brunazzi A, Scaglione D, Talini RF, Miculan M, Magni F, Poland J, Enrico Pè M, Brandolini A, Dell'Acqua M (2018) Molecular diversity and landscape genomics of the crop wild relative Triticum urartu across the Fertile Crescent. Plant J 94(4):670-684. https://doi.org/10.1111/tpj.13888

Caballero L, Martín MA, Alvarez JB (2008) Allelic variation for the high- and low-molecular-weight glutenin subunits in wild diploid wheat (Triticum urartu) and its comparison with durum wheats. Aust J Agric Res 59(10):906. https://doi.org/10.1071/AR08065

Cakmak I, Ozkan H, Braun HJ, Welch RM, Romheld V (2000) Zinc and iron concentrations in seeds of wild, primitive, and modern wheats. Food Nutr Bull 21(4):401-403. https://doi.org/10.1177/ 156482650002100411

Cakmak I, Pfeiffer WH, McClafferty B (2010) REVIEW: biofortification of durum wheat with zinc and iron. Cereal Chemistry Journal 87(1):10-20. https://doi.org/10.1094/CCHEM-87-1-0010
Cakmak I, Torun A, Millet E, Feldman M, Fahima T, Korol A, Nevo E, Braun HJ, Özkan H (2004) Triticum dicoccoides : An important genetic resource for increasing zinc and iron concentration in modern cultivated wheat. Soil Sci Pl Nutr 50(7):1047-1054. https://doi.org/10.1080/00380768.2004.10408573

Cantu D, Pearce SP, Distelfeld A, Christiansen MW, Uauy C, Akhunov E, Fahima T, Dubcovsky J (2011) Effect of the down-regulation of the high Grain Protein Content (GPC) genes on the wheat transcriptome during monocarpic senescence. BMC Genomics 12:492. https://doi.org/10.1186/1471-2164-12-492

Chatzav M, Peleg Z, Ozturk L, Yazici A, Fahima T, Cakmak I, Saranga Y (2010) Genetic diversity for grain nutrients in wild emmer wheat: potential for wheat improvement. Ann Bot 105(7):12111220. https://doi.org/10.1093/aob/mcq024

Chhuneja P, Dhaliwal HS, Bains NS, Singh K (2006) Aegilops kotschyi and aegilops tauschii as sources for higher levels of grain iron and zinc. Plant Breed 125(5):529-531. https://doi.org/10.1111/j. 1439-0523.2006.01223.x

Dempewolf H, Eastwood RJ, Guarino L, Khoury CK, Müller JV, Toll J (2014) Adapting agriculture to climate change: a global initiative to collect, conserve, and use crop wild relatives. Agroecol Sustain Food Syst 38(4):369-377. https://doi.org/10.1080/21683 565.2013.870629

Distelfeld A, Cakmak I, Peleg Z, Ozturk L, Yazici AM, Budak H, Saranga Y, Fahima T (2007) Multiple QTL-effects of wheat Gpc-B1 locus on grain protein and micronutrient concentrations. Physiol Plant 129(3):635-643. https://doi.org/10.1111/j. 1399-3054.2006.00841.x

Doebley JF, Gaut BS, Smith BD (2006) The molecular genetics of crop domestication. Cell 127(7):1309-1321. https://doi.org/10. 1016/j.cell.2006.12.006

Dubcovsky J, Dvorak J (2007) Genome plasticity a key factor in the success of polyploid wheat under domestication. Science 316(5833):1862-1866. https://doi.org/10.1126/science.1143986

El Baidouri M, Murat F, Veyssiere M, Molinier M, Flores R, Burlot L, Alaux M, Quesneville H, Pont C, Salse J (2017) Reconciling the evolutionary origin of bread wheat (Triticum aestivum). New Phytol 213(3):1477-1486. https://doi.org/10.1111/nph.14113

Erba D, Hidalgo A, Bresciani J, Brandolini A (2011) Environmental and genotypic influences on trace element and mineral concentrations in whole meal flour of einkorn (Triticum monococcum L subsp monococcum). J Cereal Sci 54(2):250-254. https://doi. org/10.1016/j.jcs.2011.06.011

Fatima F, McCallum BD, Pozniak CJ, Hiebert CW, McCartney CA, Fedak G, You FM, Cloutier S (2020) Identification of new leaf rust resistance loci in wheat and wild relatives by arraybased SNP genotyping and association genetics. Front Plant Sci 11:583738. https://doi.org/10.3389/fpls.2020.583738

Fernie AR, Yan J (2019) De novo domestication: an alternative route toward new crops for the future. Mol Plant 12(5):615-631. https://doi.org/10.1016/j.molp.2019.03.016

Geisslitz S, Longin CFH, Scherf KA, Koehler P (2019) Comparative study on gluten protein composition of ancient (einkorn, emmer and spelt) and modern wheat species (durum and common wheat). Foods (Basel, Switzerland) 8(9):409

Gibson RS, Bailey KB, Gibbs M, Ferguson EL (2010) A review of phytate, iron, zinc, and calcium concentrations in plant-based complementary foods used in low-income countries and implications for bioavailability. Food Nutr Bull 31(2 Suppl):S134-S146. https://doi.org/10.1177/15648265100312S206

Golovnina KA, Glushkov SA, Blinov AG, Mayorov VI, Adkison LR, Goncharov NP (2007) Molecular phylogeny of the genus Triticum L. P1 Syst Evol 264(3-4):195-216. https://doi.org/10.1007/ s00606-006-0478-x 
Gornicki P, Zhu H, Wang J, Challa GS, Zhang Z, Gill BS, Li W (2014) The chloroplast view of the evolution of polyploid wheat. New Phytol 204(3):704-714. https://doi.org/10.1111/nph.12931

Graham RD, Welch RM, Bouis HE (2001) Addressing micronutrient malnutrition through enhancing the nutritional quality of staple foods: Principles, perspectives and knowledge gaps. In: Advances in agronomy, Academic Press, USA

Graham RD, Welch RM, Saunders DA, Ortiz-Monasterio I, Bouis HE, Bonierbale M, de Haan S, Burgos G, Thiele G, Liria R, Meisner CA, Beebe SE, Potts MJ, Kadian M, Hobbs PR, Gupta R, Twomlow S (2007) Nutritious subsistence food systems. Elsevier, USA

Gross BL, Olsen KM (2010) Genetic perspectives on crop domestication. Trends Plant Sci 15(9):529-537. https://doi.org/10.1016/j. tplants.2010.05.008

Guo X-H, Wu B-H, Hu X-G, Bi Z-G, Wang Z-Z, Liu D-C, ZHENG Y (2013) Molecular characterization of two y-type high molecular weight glutenin subunit alleles 1 Ay 12 and 1Ay8 from cultivated einkorn wheat (Triticum monococcum ssp monococcum). Gene 516(1):1-7. https://doi.org/10.1016/j.gene.2012. 12.037

Gupta PK, Balyan HS, Sharma S, Kumar R (2020) Biofortification and bioavailability of $\mathrm{Zn}, \mathrm{Fe}$ and $\mathrm{Se}$ in wheat: present status and future prospects. Theor Appl Genet. https://doi.org/10.1007/ s00122-020-03709-7

Hammer K (1984) Das Domestikationssyndrom. Die Kulturpflanze 32(1):11-34. https://doi.org/10.1007/BF02098682

He F, Pasam R, Shi F, Kant S, Keeble-Gagnere G, Kay P, Forrest K, Fritz A, Hucl P, Wiebe K, Knox R, Cuthbert R, Pozniak C, Akhunova A, Morrell PL, Davies JP, Webb SR, Spangenberg G, Hayes B, Daetwyler H, Tibbits J, Hayden M, Akhunov E (2019) Exome sequencing highlights the role of wild-relative introgression in shaping the adaptive landscape of the wheat genome. Nat Genet 51(5):896-904. https://doi.org/10.1038/ s41588-019-0382-2

Henry RJ, Nevo E (2014) Exploring natural selection to guide breeding for agriculture. Plant Biotechnol J 12(6):655-662. https://doi.org/ 10.1111/pbi.12215

Hernández L, Afonso D, Rodríguez EM, Díaz C (2011) Phenolic compounds in wheat grain cultivars. Plant Foods Human Nutrition 66(4):408-415. https://doi.org/10.1007/s11130-011-0261-1

Heun M (1997) Site of einkorn wheat domestication identified by DNA fingerprinting. Science 278(5341):1312-1314. https://doi.org/10. $1126 /$ science.278.5341.1312

Hu XG, Liu J, Zhang L, Wu BH, Hu JL, Liu DC, Zheng YL (2017) $\mathrm{Zn}$ and $\mathrm{Fe}$ concentration variations of grain and flag leaf and the Relationship with NAM-G1 Gene in Triticum timopheevii (Zhuk) Zhuk ssp timopheevii. Cereal Res Commun 45(3):421431. https://doi.org/10.1556/0806.45.2017.022

Hu X-G (2012) Characteristics and polymorphism of NAM gene from Aegilops section sitopsis species. Afr J Agric Res. https://doi. org/10.5897/AJAR12.078

Hu X-G, Wu B-H, Bi Z-G, Liu D-C, Zhang L-Q, Yan Z-H, WEI Y, ZHENG Y (2012) Allelic variation and distribution of HMW glutenin subunit 1Ay in Triticum species. Genet Resour Crop Evol 59(4):491-497. https://doi.org/10.1007/s10722-011-9698-1

Hu X-G, Wu B-H, Liu D-C, WEI Y, Gao S-B, ZHENG Y (2013) Variation and their relationship of NAM-G1 gene and grain protein content in Triticum timopheevii Zhuk. J Plant Physiol 170(3):330-337. https://doi.org/10.1016/j.jplph.2012.10.009

Hu X-G, Wu B-H, Yan Z-H, Liu D-C, WEI Y, ZHENG Y (2010) Characterization of a novel 1 Ay gene and its expression protein in triticum urartu. Agri Sci China 9(11):1543-1552. https://doi.org/ 10.1016/S1671-2927(09)60250-9

Huang Q, Börner A, Röder S, Ganal W (2002) Assessing genetic diversity of wheat (Triticum aestivum L) germplasm using microsatellite markers. Theor Appl Genet 105(5):699-707. https://doi.org/10.1007/s00122-002-0959-4

Huang S, Sirikhachornkit A, Su X, Faris J, Gill B, Haselkorn R, Gornicki P (2002b) Genes encoding plastid acetyl-CoA carboxylase and 3-phosphoglycerate kinase of the Triticum/Aegilops complex and the evolutionary history of polyploid wheat. Proc Natl Acad Sci USA 99(12):8133-8138. https://doi.org/10.1073/pnas. 072223799

Huo N, Zhu T, Zhang S, Mohr T, Luo M-C, Lee J-Y, Distelfeld A, Altenbach S, Gu YQ (2019) Rapid evolution of $\alpha$-gliadin gene family revealed by analyzing Gli-2 locus regions of wild emmer wheat. Funct Integr Genomics 19(6):993-1005. https://doi.org/ 10.1007/s10142-019-00686-z

Iizumi T, Ali-Babiker I-EA, Tsubo M, Tahir ISA, Kurosaki Y, Kim W, Gorafi YSA, Idris AAM, Tsujimoto H (2021) Rising temperatures and increasing demand challenge wheat supply in Sudan. Nat Food 2(1):19-27. https://doi.org/10.1038/ s43016-020-00214-4

Jiang Q, Wei Y, Wang F, Wang J, Yan Z-H, Zheng Y (2009) Characterization and comparative analysis of HMW glutenin 1Ay alleles with differential expressions. BMC Plant Biol 9:16. https://doi. org/10.1186/1471-2229-9-16

Johns T, Eyzaguirre PB (2007) Biofortification, biodiversity and diet: a search for complementary applications against poverty and malnutrition. Food Policy 32(1):1-24. https://doi.org/10.1016/j. foodpol.2006.03.014

Joppa LR, Du C, Hart GE, Hareland GA (1997) Mapping gene(s) for grain protein in tetraploid wheat (Triticum turgidum L) using a population of recombinant inbred chromosome lines. Crop Sci. 37(5):1586-1589. https://doi.org/10.2135/cropsci1997.00111 $83 \mathrm{X} 003700050030 \mathrm{x}$

Kabbaj H, Sall AT, Al-Abdallat A, Geleta M, Amri A, Filali-Maltouf A, Belkadi B, Ortiz R, Bassi FM (2017) Genetic diversity within a global panel of durum wheat (triticum durum) landraces and modern germplasm reveals the history of alleles exchange. Front Plant Sci 8:1277. https://doi.org/10.3389/fpls.2017.01277

Kantar MB, Nashoba AR, Anderson JE, Blackman BK, Rieseberg LH (2017) The genetics and genomics of plant domestication. Bioscience 67(11):971-982. https://doi.org/10.1093/biosci/bix114

Khan AW, Garg V, Roorkiwal M, Golicz AA, Edwards D, Varshney RK (2020) Super-pangenome by integrating the wild side of a species for accelerated crop improvement. Trends Plant Sci 25(2):148158. https://doi.org/10.1016/j.tplants.2019.10.012

Kilian B, Dempewolf H, Guarino L, Werner P, Coyne C, Warburton ML (2021) Crop science special issue: adapting agriculture to climate change: a walk on the wild side. Crop Sci 61(1):32-36. https://doi.org/10.1002/csc2.20418

Kilian B, Mammen K, Millet E, Sharma R, Graner A, Salamini F, Hammer K, Özkan H (2011) Aegilops. In: Kole C (ed) Wild crop relatives: genomic and breeding resources. Springer, Berlin Heidelberg, Berlin, Heidelberg, pp 1-76

Kilian B, Martin W, Salamini F (2010) Genetic diversity, evolution and domestication of wheat and barley in the fertile crescent. In: Glaubrecht M (ed) Evolution in Action. Springer, Berlin Heidelberg, Berlin, Heidelberg, pp 137-166

Kilian B, Ozkan H, Deusch O, Effgen S, Brandolini A, Kohl J, Martin W, Salamini F (2007a) Independent wheat B and G genome origins in outcrossing Aegilops progenitor haplotypes. Mol Biol Evol 24(1):217-227. https://doi.org/10.1093/molbev/msl151

Kilian B, Ozkan H, Walther A, Kohl J, Dagan T, Salamini F, Martin W (2007b) Molecular diversity at 18 loci in 321 wild and 92 domesticate lines reveal no reduction of nucleotide diversity during Triticum monococcum (Einkorn) domestication: implications for the origin of agriculture. Mol Biol Evol 24(12):2657-2668. https://doi.org/10.1093/molbev/msm192 
Konovalov FA, Goncharov NP, Goryunova S, Shaturova A, Proshlyakova T, Kudryavtsev A (2010) Molecular markers based on LTR retrotransposons BARE-1 and Jeli uncover different strata of evolutionary relationships in diploid wheats. Mol Genetics Genom : MGG 283(6):551-563. https://doi.org/10.1007/ s00438-010-0539-2

Ladizinsky G (1985) Founder effect in crop-plant evolution. Econ Bot 39(2):191-199. https://doi.org/10.1007/BF02907844

Laddomada B, Caretto S, Mita G (2015) Wheat bran phenolic acids: bioavailability and stability in whole wheat-based foods. Molecules (basel, Switzerland) 20(9):15666-15685. https://doi.org/ 10.3390/molecules200915666

Laddomada B, Durante M, Mangini G, D’Amico L, Lenucci MS, Simeone R, Piarulli L, Mita G, Blanco A (2017) Genetic variation for phenolic acids concentration and composition in a tetraploid wheat (Triticum turgidum L) collection. Genet Resour Crop Evol 64(3):587-597. https://doi.org/10.1007/s10722-016-0386-Z

Li M, Dong L, Li B, Wang Z, Xie J, Qiu D, Li Y, Shi W, Yang L, Wu Q, Chen Y, Lu P, Guo G, Zhang H, Zhang P, Zhu K, Li Y, Zhang Y, Wang R, Yuan C, Liu W, Yu D, Luo M-C, Fahima T, Nevo E, Li H, Liu Z (2020a) A CNL protein in wild emmer wheat confers powdery mildew resistance. New Phytol 228(3):1027-1037. https://doi.org/10.1111/nph.16761

Li Y, Fu J, Shen Q, Yang D (2020) High-molecular-weight glutenin subunits: genetics, structures, and relation to end use qualities. Int J Mol Sci. https://doi.org/10.3390/ijms22010184

Ling H-Q, Ma B, Shi X, Liu H, Dong L, Sun H, Cao Y, Gao Q, Zheng S, Li Y, Yu Y, Du H, Qi M, Li Y, Lu H, Yu H, Cui Y, Wang N, Chen C, Wu H, Zhao Y, Zhang J, Li Y, Zhou W, Zhang B, Hu W, van Eijk MJT, Tang J, Witsenboer HMA, Zhao S, Li Z, Zhang A, Wang D, Liang C (2018) Genome sequence of the progenitor of wheat a subgenome Triticum urartu. Nature 557(7705):424-428. https://doi.org/10.1038/s41586-018-0108-0

Liyana-Pathirana CM, Shahidi F (2006) Importance of insoluble-bound phenolics to antioxidant properties of wheat. J Agric Food Chem 54(4):1256-1264. https://doi.org/10.1021/jf052556h

Luo M-C, Gu YQ, Puiu D, Wang H, Twardziok SO, Deal KR, Huo N, Zhu T, Wang Le, Wang Y, McGuire PE, Liu S, Long H, Ramasamy RK, Rodriguez JC, Van SL, Yuan L, Wang Z, Xia Z, Xiao L, Anderson OD, Ouyang S, Liang Y, Zimin AV, Pertea G, Qi P, Bennetzen JL, Dai X, Dawson MW, Müller H-G, Kugler K, Rivarola-Duarte L, Spannagl M, Mayer KFX, Lu F-H, Bevan MW, Leroy P, Li P, You FM, Sun Q, Liu Z, Lyons E, Wicker T, Salzberg SL, Devos KM, Dvořák J (2017) Genome sequence of the progenitor of the wheat $\mathrm{D}$ genome Aegilops tauschii. Nature 551(7681):498-502. https://doi.org/10.1038/nature24486

Luo M-C, Yang Z-L, You FM, Kawahara T, Waines JG, Dvorak J (2007) The structure of wild and domesticated emmer wheat populations, gene flow between them, and the site of emmer domestication. Theor Appl Genet 114(6):947-959. https://doi. org/10.1007/s00122-006-0474-0

Maccaferri M, Harris NS, Twardziok SO, Pasam RK, Gundlach H, Spannagl M, Ormanbekova D, Lux T, Prade VM, Milner SG, Himmelbach A, Mascher M, Bagnaresi P, Faccioli P, Cozzi P, Lauria M, Lazzari B, Stella A, Manconi A, Gnocchi M, Moscatelli M, Avni R, Deek J, Biyiklioglu S, Frascaroli E, Corneti S, Salvi S, Sonnante G, Desiderio F, Marè C, Crosatti C, Mica E, Özkan H, Kilian B, de Vita P, Marone D, Joukhadar R, Mazzucotelli E, Nigro D, Gadaleta A, Chao S, Faris JD, Melo ATO, Pumphrey M, Pecchioni N, Milanesi L, Wiebe K, Ens J, MacLachlan RP, Clarke JM, Sharpe AG, Koh CS, Liang KYH, Taylor GJ, Knox R, Budak H, Mastrangelo AM, Xu SS, Stein N, Hale I, Distelfeld A, Hayden MJ, Tuberosa R, Walkowiak S, Mayer KFX, Ceriotti A, Pozniak CJ, Cattivelli L (2019) Durum wheat genome highlights past domestication signatures and future improvement targets. Nat Genet 51(5):885-895. https://doi.org/ 10.1038/s41588-019-0381-3

Martínez-Moreno F, Solís I, Noguero D, Blanco A, Özberk İ, Nsarellah N, Elias E, Mylonas I, Soriano JM (2020) Durum wheat in the Mediterranean Rim: historical evolution and genetic resources. Genet Resour Crop Evol 67(6):1415-1436. https://doi.org/10. 1007/s10722-020-00913-8

Meyer RS, Purugganan MD (2013) Evolution of crop species: genetics of domestication and diversification. Nat Rev Genet 14(12):840 852. https://doi.org/10.1038/nrg3605

Molberg O, Uhlen AK, Jensen T, Flaete NS, Fleckenstein B, ArentzHansen H, Raki M, Lundin KEA, Sollid LM (2005) Mapping of gluten T-cell epitopes in the bread wheat ancestors: implications for celiac disease. Gastroenterology 128(2):393-401. https://doi. org/10.1053/j.gastro.2004.11.003

Monasterio I, Graham RD (2000) Breeding for trace minerals in Wheat. Food Nutr Bull 21(4):392-396. https://doi.org/10.1177/15648 2650002100409

Moragues M, Moralejo M, Sorrells ME, Royo C (2007) Dispersal of durum wheat [Triticum turgidum L. ssp. turgidum convar. durum (Desf.) MacKey] landraces across the Mediterranean basin assessed by AFLPs and microsatellites. Genet Res Crop Evolution 54(5):1133-1144. https://doi.org/10.1007/ s10722-006-9005-8

Morgounov A, Gómez-Becerra HF, Abugalieva A, Dzhunusova M, Yessimbekova M, Muminjanov H, Zelenskiy Y, Ozturk L, Cakmak I (2007) Iron and zinc grain density in common wheat grown in Central Asia. Euphytica 155(1-2):193-203. https:// doi.org/10.1007/s10681-006-9321-2

Mori N, Kondo Y, Ishii T, Kawahara T, Valkoun J, Nakamura C (2009) Genetic diversity and origin of timopheevi wheat inferred by chloroplast DNA fingerprinting. Breed Sci 59:571-578

Morrison L (1993) Triticum-Aegilops systematics: taking an integrative approach

Narang D, Kaur S, Steuernagel B, Ghosh S, Bansal U, Li J, Zhang P, Bhardwaj S, Uauy C, Wulff BBH, Chhuneja P (2020) Discovery and characterisation of a new leaf rust resistance gene introgressed in wheat from wild wheat Aegilops peregrina. Sci Rep 10(1):7573. https://doi.org/10.1038/s41598-020-64166-2

Neelam K, Tiwari VK, Rawat N, Tripathi SK, Randhawa GS, Dhaliwal HS (2010) Identification of Aegilops species with higher production of phytosiderophore and iron and zinc uptake under micronutrient-sufficient and -deficient conditions. Plant Genet Res 8(2):132-141. https://doi.org/10.1017/S1479262110000080

Nsarellah N, Amri A, Nachit MM, Bouhssini MEL, Lhaloui S, Lorenzoni C (2003) New durum wheat with Hessian fly resistance from Triticum araraticum and T carthlicum in Morocco. Plant Breed 122(5):435-437. https://doi.org/10.1046/j.1439-0523. 2003.00871.x

Oliveira HR, Jacocks L, Czajkowska BI, Kennedy SL, Brown TA (2020) Multiregional origins of the domesticated tetraploid wheats. PLoS ONE 15(1):e0227148. https://doi.org/10.1371/ journal.pone. 0227148

Oury F-X, Leenhardt F, Rémésy C, Chanliaud E, Duperrier B, Balfourier F, Charmet G (2006) Genetic variability and stability of grain magnesium, zinc and iron concentrations in bread wheat. Eur $\mathbf{J}$ Agron 25(2):177-185. https://doi.org/10.1016/j.eja.2006.04.011

Ozkan H, Brandolini A, Pozzi C, Effgen S, Wunder J, Salamini F (2005) A reconsideration of the domestication geography of tetraploid wheats. Theor Appl Genet 110(6):1052-1060. https:// doi.org/10.1007/s00122-005-1925-8

Ozkan H, Brandolini A, Torun A, AltIntas S, Eker S, Kilian B, Braun HJ, Salamini F, Cakmak I (2007) Natural variation and identification of microelements content in seeds of einkorn wheat (triticum monococcum). In: Buck HT, Nisi JE, Salomón N (eds) 
Wheat production in stressed environments, vol 12. Springer. Netherlands, Dordrecht, pp 455-462

Özkan H, Willcox G, Graner A, Salamini F, Kilian B (2011) Geographic distribution and domestication of wild emmer wheat (Triticum dicoccoides). Genet Resour Crop Evol 58(1):11-53. https://doi.org/10.1007/s10722-010-9581-5

Ozuna CV, Barro F (2018) Characterization of gluten proteins and celiac disease-related immunogenic epitopes in the Triticeae: cereal domestication and breeding contributed to decrease the content of gliadins and gluten. Mol Breed. https://doi.org/10. 1007/s11032-018-0779-0

Ozuna CV, Iehisa JCM, Giménez MJ, Alvarez JB, Sousa C, Barro F (2015) Diversification of the celiac disease $\alpha$-gliadin complex in wheat: a 33-mer peptide with six overlapping epitopes, evolved following polyploidization. Plant J 82(5):794-805. https://doi. org/10.1111/tpj.12851

Payne PI, Holt LM, Jackson EA, Law CN (1984) Wheat storage proteins: their genetics and their potential for manipulation by plant breeding. Phil Trans r Soc Lond B 304(1120):359-371. https:// doi.org/10.1098/rstb.1984.0031

Payne PI, Law CN, Mudd EE (1980) Control by homoeologous group 1 chromosomes of the high-molecular-weight subunits of glutenin, a major protein of wheat endosperm. Theor Appl Genet 58(3-4):113-120. https://doi.org/10.1007/BF00263101

Pearce S, Tabbita F, Cantu D, Buffalo V, Avni R, Vazquez-Gross H, Zhao R, Conley CJ, Distelfeld A, Dubcovksy J (2014) Regulation of $\mathrm{Zn}$ and $\mathrm{Fe}$ transporters by the GPC1 gene during early wheat monocarpic senescence. BMC Plant Biol 14:368. https://doi.org/ 10.1186/s12870-014-0368-2

Peleg Z, Cakmak I, Ozturk L, Yazici A, Jun Y, Budak H, Korol AB, Fahima T, Saranga Y (2009) Quantitative trait loci conferring grain mineral nutrient concentrations in durum wheat $\mathrm{x}$ wild emmer wheat RIL population. Theor Appl Genet 119(2):353369. https://doi.org/10.1007/s00122-009-1044-Z

Peleg Z, Saranga Y, Yazici A, Fahima T, Ozturk L, Cakmak I (2008) Grain zinc, iron and protein concentrations and zinc-efficiency in wild emmer wheat under contrasting irrigation regimes. Plant Soil 306(1-2):57-67. https://doi.org/10.1007/s11104-007-9417-z

Petersen G, Seberg O, Yde M, Berthelsen K (2006) Phylogenetic relationships of Triticum and Aegilops and evidence for the origin of the A, B, and D genomes of common wheat (Triticum aestivum). Mol Phylogenet Evol 39(1):70-82. https://doi.org/10. 1016/j.ympev.2006.01.023

Pizzuti D, Buda A, D'Odorico A, D'Incà R, Chiarelli S, Curioni A, Martines D (2006) Lack of intestinal mucosal toxicity of Triticum monococcum in celiac disease patients. Scand J Gastroenterol 41(11):1305-1311. https://doi.org/10.1080/0036552060 0699983

Pont C, Leroy T, Seidel M, Tondelli A, Duchemin W, Armisen D, Lang D, Bustos-Korts D, Goué N, Balfourier F, Molnár-Láng M, Lage J, Kilian B, Özkan H, Waite D, Dyer S, Letellier T, Alaux M, Russell J, Keller B, van Eeuwijk F, Spannagl M, Mayer KFX, Waugh R, Stein N, Cattivelli L, Haberer G, Charmet G, Salse J (2019) Tracing the ancestry of modern bread wheats. Nat Genet 51(5):905-911. https://doi.org/10.1038/s41588-019-0393-z

Prasad AS, Halsted JA, Nadimi M (1961) Syndrome of iron deficiency anemia, hepatosplenomegaly, hypogonadism, dwarfism and geophagia. Am J Med 31(4):532-546. https://doi.org/10.1016/ 0002-9343(61)90137-1

Przewieslik-Allen AM, Wilkinson PA, Burridge AJ, Winfield MO, Dai X, Beaumont M, King J, Yang C-Y, Griffiths S, Wingen LU, Horsnell R, Bentley AR, Shewry P, Barker GLA, Edwards KJ (2021) The role of gene flow and chromosomal instability in shaping the bread wheat genome. Nature Plants 7(2):172-183. https://doi.org/10.1038/s41477-020-00845-2
Purugganan MD, Fuller DQ (2009) The nature of selection during plant domestication. Nature 457(7231):843-848. https://doi.org/ 10.1038/nature07895

Qi P-F, Yue Y-W, Long H, Wei Y, Yan Z-H, Zheng Y (2006) Molecular characterization of alpha-gliadin genes from wild emmer wheat (Triticum dicoccoides). DNA sequence : J DNA Sequencing Map 17(6):415-421. https://doi.org/10.1080/10425170600931601

Rawat N, Tiwari VK, Singh N, Randhawa GS, Singh K, Chhuneja P, Dhaliwal HS (2009) Evaluation and utilization of Aegilops and wild Triticum species for enhancing iron and zinc content in wheat. Genet Resour Crop Evol 56(1):53-64. https://doi.org/10. 1007/s10722-008-9344-8

Rogers WJ, Miller TE, Payne PI, Seekings JA, Sayers EJ, Holt LM, Law CN (1997) Introduction to bread wheat (Triticum aestivum L.) and assessment for bread-making quality of alleles from $\mathrm{T}$. boeoticum Boiss. ssp. thaoudar at Introduction to bread wheat (Triticum aestivum L.) and assessment for Glu-A1 bread-making quality of alleles from $\mathrm{T}$. boeoticum Boiss. ssp. thaoudar at encoding two high-molecular-weight subunits of glutenin. Euphytica 93(1):19-29. doi: https://doi.org/10.1023/A:10029 91206350

Ross-Ibarra J, Morrell PL, Gaut BS (2007) Plant domestication, a unique opportunity to identify the genetic basis of adaptation. Proc Natl Acad Sci USA 104(Suppl 1):8641-8648. https://doi. org/10.1073/pnas.0700643104

Ruiz-Carnicer Á, Comino I, Segura V, Ozuna CV, Moreno MdL, López-Casado MÁ, Torres MI, Barro F, Sousa C (2019) Celiac immunogenic potential of $\alpha$-gliadin epitope variants from triticum and aegilops species. Nutrients. https://doi.org/10.3390/ nu11020220

Salamini F, Ozkan H, Brandolini A, Schäfer-Pregl R, Martin W (2002) Genetics and geography of wild cereal domestication in the near east. Nat Rev Genet 3(6):429-441. https://doi.org/ $10.1038 / \operatorname{nrg} 817$

Salentijn EM, Goryunova SV, Bas N, van der Meer IM, van den Broeck HC, Bastien T, Gilissen LJWJ, Smulders MJM (2009) Tetraploid and hexaploid wheat varieties reveal large differences in expression of alpha-gliadins from homoeologous Gli-2 loci. BMC Genomics 10:48. https://doi.org/10.1186/ 1471-2164-10-48

Schaart JG, Salentijn EMJ, Goryunova SV, Chidzanga C, Esselink DG, Gosman N, Bentley AR, Gilissen LJWJ, Smulders MJM (2020) Exploring the alpha-gliadin locus: the 33-mer peptide with six overlapping coeliac disease epitopes in Triticum aestivum is derived from a subgroup of Aegilops tauschii. Plant J. https://doi.org/10.1111/tpj.15147

Schalk K, Lang C, Wieser H, Koehler P, Scherf KA (2017) Quantitation of the immunodominant 33-mer peptide from $\alpha$-gliadin in wheat flours by liquid chromatography tandem mass spectrometry. Sci Rep 7:45092. https://doi.org/10.1038/srep45092

Serpen A, Gökmen V, Karagöz A, Köksel H (2008) Phytochemical quantification and total antioxidant capacities of emmer (Triticum dicoccon Schrank) and einkorn (Triticum monococcum L.) wheat landraces. J Agri Food Chem 56(16):7285-7292. https://doi.org/10.1021/jf8010855

Sharma S, Schulthess AW, Bassi FM, Badaeva ED, Neumann K, Graner A, Özkan H, Werner P, Knüpffer H, Kilian B (2021) Introducing beneficial alleles from plant genetic resources into the wheat germplasm. Biology 10(10):982. https://doi.org/10. 3390/biology10100982

Shewry PR, Hey S (2015) Do "ancient" wheat species differ from modern bread wheat in their contents of bioactive components? J Cereal Sci 65:236-243. https://doi.org/10.1016/j.jcs.2015.07. 014

Shewry P (2019) What is gluten-why is it special? Front Nutr 6:101. https://doi.org/10.3389/fnut.2019.00101 
Shiferaw B, Smale M, Braun H-J, Duveiller E, Reynolds M, Muricho $\mathrm{G}$ (2013) Crops that feed the world 10 past successes and future challenges to the role played by wheat in global food security. Food Sec. 5(3):291-317. https://doi.org/10.1007/ s12571-013-0263-y

Singh K, Chugh V, Sahi GK, Chhuneja P (2012) Wheat: mechanisms and genetic means for improving heat tolerance. In: Tuteja $\mathrm{N}$ (ed) Improving crop resistance to abiotic stress. Wiley-Blackwell, Weinheim

Smýkal P, Nelson M, Berger J, von Wettberg E (2018) The impact of genetic changes during crop domestication. Agronomy 8(7):119. https://doi.org/10.3390/agronomy8070119

Spaenij-Dekking L, Kooy-Winkelaar Y, van Veelen P, Drijfhout JW, Jonker H, van Soest L, Smulders MJM, Bosch D, Gilissen LJWJ, Koning F (2005) Natural variation in toxicity of wheat: potential for selection of nontoxic varieties for celiac disease patients. Gastroenterology 129(3):797-806. https://doi.org/10.1053/j.gastro. 2005.06.017

Stein AJ (2010) Global impacts of human mineral malnutrition. Plant Soil 335(1-2):133-154. https://doi.org/10.1007/ s11104-009-0228-2

Stetter MG, Gates DJ, Mei W, Ross-Ibarra J (2017) How to make a domesticate. Current Biology : CB 27(17):R896-R900. https:// doi.org/10.1016/j.cub.2017.06.048

Tanksley SD, McCouch SR (1997) Seed banks and molecular maps: unlocking genetic potential from the wild. Science 277(5329):1063-1066. https://doi.org/10.1126/science.277. 5329.1063

Trnka M, Rötter RP, Ruiz-Ramos M, Kersebaum KC, Olesen JE, Žalud Z, Semenov MA (2014) Adverse weather conditions for European wheat production will become more frequent with climate change. Nature Clim Change 4(7):637-643. https://doi.org/10. 1038/nclimate2242

Uauy C, Brevis JC, Dubcovsky J (2006a) The high grain protein content gene Gpc-B1 accelerates senescence and has pleiotropic effects on protein content in wheat. J Exp Bot 57(11):2785-2794. https://doi.org/10.1093/jxb/erl047

Uauy C, Distelfeld A, Fahima T, Blechl A, Dubcovsky J (2006) A NAC Gene regulating senescence improves grain protein, zinc, and iron content in wheat. Science (New York, N.Y.) 314(5803):1298-1301. https://doi.org/10.1126/science.1133649

Vaccino P, Becker H-A, Brandolini A, Salamini F, Kilian B (2009) A catalogue of Triticum monococcum genes encoding toxic and immunogenic peptides for celiac disease patients. Mol Genet Genomics : MGG 281(3):289-300. https://doi.org/10.1007/ s00438-008-0412-8

van den Broeck H, Hongbing C, Lacaze X, Dusautoir J-C, Gilissen L, Smulders M, van der Meer I (2010) In search of tetraploid wheat accessions reduced in celiac disease-related gluten epitopes. Mol BioSyst 6(11):2206-2213. https://doi.org/10.1039/c0mb00046a

van Herpen TWJM, Goryunova SV, van der Schoot J, Mitreva M, Salentijn E, Vorst O, Schenk MF, van Veelen PA, Koning F, van Soest LJM, Vosman B, Bosch D, Hamer RJ, Gilissen LJWJ, Smulders MJM (2006) Alpha-gliadin genes from the A, B, and $\mathrm{D}$ genomes of wheat contain different sets of celiac disease epitopes. BMC Genomics 7:1. https://doi.org/10.1186/ 1471-2164-7-1

Waines JG, Payne PI (1987) Electrophoretic analysis of the highmolecular-weight glutenin subunits of Triticum monococcum, T. urartu, and the A genome of bread wheat (T. aestivum). Theor Appl Genet 74(1):71-76. https://doi.org/10.1007/BF00290086

Walkowiak S, Gao L, Monat C, Haberer G, Kassa MT, Brinton J, Ramirez-Gonzalez RH, Kolodziej MC, Delorean E, Thambugala D, Klymiuk V, Byrns B, Gundlach H, Bandi V, Siri JN, Nilsen K, Aquino C, Himmelbach A, Copetti D, Ban T, Venturini L, Bevan M, Clavijo B, Koo D-H, Ens J, Wiebe K, N'Diaye A, Fritz AK,
Gutwin C, Fiebig A, Fosker C, Fu BX, Accinelli GG, Gardner KA, Fradgley N, Gutierrez-Gonzalez J, Halstead-Nussloch G, Hatakeyama M, Koh CS, Deek J, Costamagna AC, Fobert P, Heavens D, Kanamori H, Kawaura K, Kobayashi F, Krasileva K, Kuo T, McKenzie N, Murata K, Nabeka Y, Paape T, Padmarasu S, Percival-Alwyn L, Kagale S, Scholz U, Sese J, Juliana P, Singh R, Shimizu-Inatsugi R, Swarbreck D, Cockram J, Budak H, Tameshige T, Tanaka T, Tsuji H, Wright J, Wu J, Steuernagel B, Small I, Cloutier S, Keeble-Gagnère G, Muehlbauer G, Tibbets J, Nasuda S, Melonek J, Hucl PJ, Sharpe AG, Clark M, Legg E, Bharti A, Langridge P, Hall A, Uauy C, Mascher M, Krattinger SG, Handa H, Shimizu KK, Distelfeld A, Chalmers K, Keller B, Mayer KFX, Poland J, Stein N, McCartney CA, Spannagl M, Wicker T, Pozniak CJ (2020) Multiple wheat genomes reveal global variation in modern breeding. Nature. https://doi. org/10.1038/s41586-020-2961-x

Wan Y, Wang D, Shewry R, Halford G (2002) Isolation and characterization of five novel high molecular weight subunit of glutenin genes from Triticum timopheevi and Aegilops cylindrica. Theor Appl Genet 104(5):828-839. https://doi.org/10.1007/ s00122-001-0793-0

Wang J, Luo M-C, Chen Z, You FM, Wei Y, Zheng Y, Dvorak J (2013) Aegilops tauschii single nucleotide polymorphisms shed light on the origins of wheat D-genome genetic diversity and pinpoint the geographic origin of hexaploid wheat. New Phytol 198(3):925937. https://doi.org/10.1111/nph.12164

Wang Z, Huang L, Wu B, Hu J, Jiang Z, Qi P, Zheng Y, Liu D (2018) Characterization of an Integrated active glu-1ay allele in common wheat from wild emmer and its potential role in flour improvement. Int J Mol Sci. https://doi.org/10.3390/ijms19040923

Waters BM, Uauy C, Dubcovsky J, Grusak MA (2009) Wheat (Triticum aestivum) NAM proteins regulate the translocation of iron, zinc, and nitrogen compounds from vegetative tissues to grain. J Exp Bot 60(15):4263-4274. https://doi.org/10.1093/jxb/erp257

Weissgerber TL, Milic NM, Winham SJ, Garovic VD (2015) Beyond bar and line graphs: time for a new data presentation paradigm. PLoS Biol 13(4):e1002128. https://doi.org/10.1371/journal.pbio. 1002128

Wieser H (2007) Chemistry of gluten proteins. Food Microbiol 24(2):115-119. https://doi.org/10.1016/j.fm.2006.07.004

Xie X, Liu Y-G (2021) De novo domestication towards new crops. National Sci Rev. https://doi.org/10.1093/nsr/nwab033

Xu L-L, Li W, Wei Y, Zheng Y (2009) Genetic diversity of HMW glutenin subunits in diploid, tetraploid and hexaploid Triticum species. Genet Resour Crop Evol 56(3):377-391. https://doi.org/ 10.1007/s10722-008-9373-3

Yildirim F, Akkaya MS (2006) DNA Fingerprinting and Genetic Characterization of Anatolian Triticum spp using AFLP Markers. Genet Resour Crop Evol 53(5):1033-1042. https://doi.org/10. 1007/s10722-004-7938-3

Yilmaz VA, Brandolini A, Hidalgo A (2015) Phenolic acids and antioxidant activity of wild, feral and domesticated diploid wheats. J Cereal Sci 64:168-175. https://doi.org/10.1016/j.jcs.2015.05.005

Zaharieva M, Monneveux P (2014) Cultivated einkorn wheat (Triticum monococcum L subsp monococcum): the long life of a founder crop of agriculture. Genet Resour Crop Evol 61(3):677-706. https://doi.org/10.1007/s10722-014-0084-7

Zhang Y, Luo G, Liu D, Wang D, Yang W, Sun J, Zhang A, Zhan K (2015) Genome-, transcriptome- and proteome-wide analyses of the gliadin gene families in triticum urartu. PLoS ONE 10(7):e0131559. https://doi.org/10.1371/journal.pone.0131559

Zhao C, Liu B, Piao S, Wang X, Lobell DB, Huang Y, Huang M, Yao Y, Bassu S, Ciais P, Durand J-L, Elliott J, Ewert F, Janssens IA, Li T, Lin E, Liu Q, Martre P, Müller C, Peng S, Peñuelas J, Ruane AC, Wallach D, Wang T, Wu D, Liu Z, Zhu Y, Zhu Z, Asseng S (2017) Temperature increase reduces global yields of 
major crops in four independent estimates. Proc Natl Acad Sci USA 114(35):9326-9331. https://doi.org/10.1073/pnas.17017 62114

Zhao FJ, Su YH, Dunham SJ, Rakszegi M, Bedo Z, McGrath SP, Shewry PR (2009) Variation in mineral micronutrient concentrations in grain of wheat lines of diverse origin. J Cereal Sci 49(2):290-295. https://doi.org/10.1016/j.jcs.2008.11.007

Zohary D (2004) Unconscious selection and the evolution of domesticated plants. Econ Bot 58(1):5-10. https://doi.org/10.1663/00130001(2004)058[0005:USATEO]2.0.CO;2

Zohary D, Hopf M, Weiss E (2012) Domestication of plants in the old world: the origin and spread of domesticated plants in Southwest Asia, Europe, and the Mediterranean Basin. Oxford University Press. https://doi.org/10.1093/acprof:osobl/9780199549061.001. 0001

Zsögön A, Cermak T, Voytas D, Peres LEP (2017) Genome editing as a tool to achieve the crop ideotype and de novo domestication of wild relatives: Case study in tomato. Plant Sci : Int J Exp Plant Biol 256:120-130. https://doi.org/10.1016/j.plantsci.2016.12.012
Zsögön A, Čermák T, Naves ER, Notini MM, Edel KH, Weinl S, Freschi L, Voytas DF, Kudla J, Peres LEP (2018) De novo domestication of wild tomato using genome editing. Nat Biotechnol. https://doi.org/10.1038/nbt.4272

\section{Online Resource}

International Grains Council [IGC] (2020). World Grain Statistics 2016. Available: https://www.igc.int/en/subscriptions/subscripti on.aspx. Accessed 3 May 2021

Publisher's Note Springer Nature remains neutral with regard to jurisdictional claims in published maps and institutional affiliations. 